






\section{BOOKS BY H. E. PARKHURST}

SONG BIRDS AND WATERFOWL. Illustrated by Louis

Agassiz Fuertes, $12 \mathrm{mo}$, net, . . . . . . . \$1.50

THE BIRDS' CALENDAR. With 24 Illustrations. 12 mo, net, 1.50 
HOW TO NAME THE BIRDS 



\section{HOW TO NAME THE BIRDS}

A POCKET GUIDE TO ALL THE LAND BIRDS AND TO THE PRINCIPAL WATER FOWL NORMALLY FOUND IN THE NEW ENGLAND STATES, NEW YORK, PENNSYLVANIA AND NEW JERSEY, FOR THE USE OF FIELD ORNITHOLOGISTS

Q 683

P23X

1898

Birds
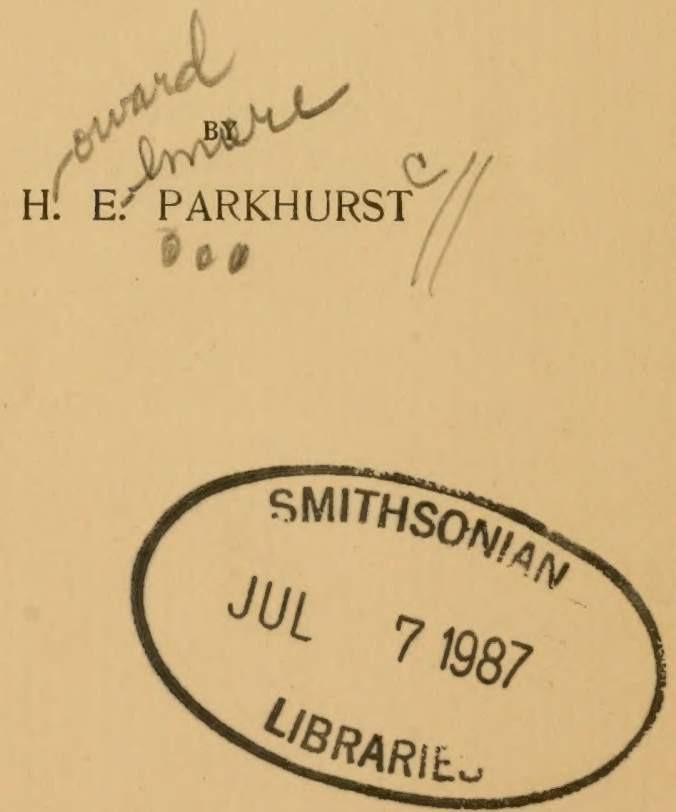

NEW YORK

CHARLES SCRIBNER'S SONS 
COPYRIGHT, I898, BY

\section{CHARLES SCRIBNER'S SONS}

TROW DIRECTORY

PRINTING AND BOOKBINDING CONPANY NEW YORK 


\section{TO}

\section{ALL BIRD LOVERS}

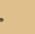





\section{HOW TO NAME THE BIRDS}

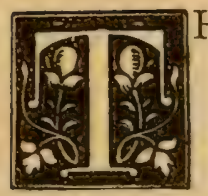

HIS little work is a new departure in birdclassification, to aid the field-ornithologist in determining an unknown species. It is in no sense a rival of the excellent manuals on the subject now extant, but is rather an introduction to their more general use.

One of the great obstacles to a wider study of ornithology is the helplessness of the beginner, especially when studying by himself, to identify his specimens. If he takes up one of the standard authorities, he is confronted by a ponderous volume of four hundred to eight hundred pages, describing some hundreds of species of all sorts, sizes, and colors, most confusedly mingled. Moreover, many of the details of bird-anatomy, always given in ornithological manuals, are utterly invisible at field-range, and such multiplicity of data, unsystematically arranged as they commonly are, hinders a quick and clear idea of the species that is being described; on the other hand, those aspects that constantly appeal to the observer-color, size, and periods of appearancehave no place in the current scheme of classification. As a result, species only to be seen months apart, and 
utterly unlike in size and color, are described almost side by side on the same page; diminutive kinglets, smaller than the chipping sparrow, and seen only in winter, are brought strangely close to summer robins and thrushes, and the microscopic humming-bird has to fraternize with the nighthawk and the woodpecker. This is not said in disparagement of scientific classification, but to call attention to its inadequacy for the needs of one who prosecutes the study from an entirely different standpoint, as is the case with the great majority of field-observers. It is to be remembered that one will be led up to a systematic and exhaustive study of this subject only through the more attractive discoveries in out-door exploration. Having determined his species from this "guide," he will naturally refer to some standard manual for its interesting details of life-history, of which only an outline is here given.

As regards the times when the various birds can be found in a given locality, they naturally fall into four quite distinct groups. The first group comprises those species that arrive from the south in spring, and remain till they return south in fall; the second, those that come down from the north in fall, and return north in spring; the third, those that winter in the south, and summer far north, and can therefore be seen only a few days or weeks, twice a year, in their passage to and fro; and, in the fourth group, are such as can be seen throughout the year. This fourfold division into summer, winter, migrant, and permanent groups is at the 
basis of our present classification. Standing quite apart, and in every aspect perfectly distinct from all other species, are the birds of prey-eagles, hawks (and allies), and owls-forming a fifth group at the end of the book.

The first four groups are subgrouped according to color. Two very common and striking colors in birds are black and yellow, which afford the basis of a fivefold color-grouping-neutral (with no strong tint), black (without yellow), yellow (without black), black and yellow, and the remainder forming the blue or red list. The larger color-groups are further subdivided, according to conspicuous differences, so that the ultimate groups contain only from two to ten species, generally about six, in which to find the given specimen. The species of each ultimate group are arranged according to size.

To enable the student to glance quickly through a number of species, their description is arranged as follows: Below the name of the species is its summarized description in two parts, separated by a dash, the first describing the prevailing appearance of the upper side of the bird (with or without wings and tail, which are commonly darker), the second, that of the lower side, primarily throat, breast, and sides, which are most conspicuous. This summary is to be regarded as the precise description of the entire bird, cxcept as modified by further details. If two terms are used in either part of the summary (except "streaked" or "spotted "), the first applies to the fore-part of the respective side. If 
only a single term is used in the summary, it applies to both upper and under sides, as in the case of the crow, whose summary is "black." When the summary contains two terms, not separated by a dash, both apply equally to upper and under sides. After the summary are the descriptive details: first, the length, in inches, then the various specific points of color-above, proceeding from bill to tail; below, from throat to rear. By this condensation, and the omission of many points usually given in books, but perfectly useless to the field-observer, the entire avifauna of the given area, excepting the migrant water-fowl, has been described in about a hundred pages.

The description is that of the adult male in spring plumage, which shows the most intense color and the most characteristic markings. In fall his colors are often faded, and certain markings absent. In many species male and female are indistinguishable; in some, as the robin, with essentially the same coloring, the female is duller, and in some the sexes are distinctly different; in the last case the female is also described. The male usually attains full plumage in the second year, i.e., in the first spring after he is hatched; but rarely not until the second spring, or even later. For a list of the few species in which the sexes have little or no resemblance, see page I9. In these cases the female is often recognizable by being in the company of the male. In a few other species the female shows restricted markings, chiefly on head and neck. But such instances are 
exceptional. In all species the male seems to be chiefly in evidence, and, in general, his spring plumage suffices to identify both sexes throughout the year.

In several cases the same species has been put into more than one list; as where a characteristic color is very inconspicuous, or where a tint is ambiguous. One might see the cat-bird twenty times without detecting the red under tail-coverts; and the blotch on the songsparrow's breast sometimes looks black, and sometimes dark brown. A very dark color often passes for black at a distance.

The various sparrows offer more difficulty than any other family of land-birds, owing to the minuteness of their distinctive markings. Yet the "sparrow-garb" is so characteristic that the student will often know his specimen to be a sparrow, long before he has determined the species. As an aid to identification, the numbers under which the detailed descriptions of all the sparrows are to be found, are stated collectively on page $\mathrm{r} 8$.

"Black" includes also blackish.

Under the term "red " is included every shade from chestnut to scarlet. A species showing red will often be more easily identified by referring to the red list of land and water birds, finding its detailed description under its proper number.

After the physical description, is given, in smaller type, an outline of life-history-distribution in territory (if no mention is made of this point, the species is found to a considerable extent in all the States, though not 
uniformly throughout each State), character and location of nest, number of eggs, with approximate date when the first set may be found (most species have two, and a few have three, broods a year, at intervals of about five weeks), and, finally, any marked peculiarity of habit. A peculiarity either in physical appearance or in habit that is quite significant of the species, and largely to be relied upon for identification, is always in italics.

The territory covered by this book is the best ornithologically explored region in America, viz., the six New England States, New York, Pennsylvania, and New Jersey-practically all the Eastern and Middle States. The avifauna of this area is largely the same throughout, yet showing noticeable differences in different sections, since within the territory are represented three zoölogical areas - the Canadian (including the northern part of the States of Maine, New Hampshire, and Vermont, the Adirondack region of New York, and the higher mountains of Pennsylvania), the Alleghanian (including the rest of New England, and of New York, and parts of Pennsylvania and New Jersey), and the Carolinian (overlapping the Alleghanian in southeastern New York and the valley of the lower Connecticut River, and including large portions of Pennsylvania and New Jersey). The avifaunas of these diverse areas show certain distinctive features, each characterized by peculiar species, and by a greater or less abundance of such as are common to the others. Thus the "migrants" belonging to the Canadian fauna summer only in northern New 
Hampshire, ctc., while southeastern New York is at once the southern boundary of those peculiar to the Alleghanian fauna, and the northern boundary of those peculiar to the Carolinian fauna; which explains why southeastern New York is so often referred to in stating the distribution of species.

While the ornithological exploration of New York has perhaps been as thorough as that of the other States, the results have not yet been systematized and tabulated, as in New England, Pennsylvania, and New Jersey. But by consulting local lists compiled in the northern, central, southeastern, and western parts of the State, with the knowledge that its avifauna is essentially Alleghanian, and, from its situation, is almost utterly precluded from having species distinct from those of Pennsylvania, it is evident that the various portions are closely identical with corresponding latitudes in New England. It is therefore to be understood that, when a New England State is named as a limit of distribution, the same is approximately true of the corresponding latitude in New York.

Special attention has been given to the birds of Pennsylvania, whose varied topography of mountain, plain, lake, and stream secures for it the richest avifauna of all the territory. The "Mts. of Pa.," so often alluded to in the following pages, refers to the Appalachian rangea mountainous belt two hundred miles broad (one-quarter of the State), running nearly north and south in the central and eastern parts, and composed of numerous 
small ranges interspersed with valleys. The highest mountains seldom exceed 2,000 feet, while many portions of the belt are only high and rugged hills. But elevation being equivalent to northern latitude, this region is largely Canadian in climate, and retains in summer many species 'not found elsewhere, except on the " northern edge ;" on the other hand, the southern latitude of the lowlands induces many species to remain in winter that move southward from New England and New York in the fall. Moreover, though not a seaboard State, its large rivers and fifty-mile shore-line of Lake Erie attract many marine species in winter, and waterfowl are more largely represented throughout Pennsylvania than in any other State.

In such a work the water-fowl must not be ignored; yet it would not be feasible to present chis branch of our avifauna with the same thoroughness as the land division, since the majority of water-birds are simply migrants along the coast, and practically inaccessible to almost all students. It has, therefore, seemed sufficient for the purpose of this book to mention only those few that sum. mer within the territory, those that migrate inland, and the commonest that are found on the coast and inland during the winter.

The Analytical Key is indispensable for quickly rrac ing a species to its proper number. It is analogous to any botanical key, and is prefaced by full directions But, to make its use perfectly understood, let us illustrate the method of learning the name of an unknown 
specimen. In winter one often sees a flock of small birds having the entire upper side of body and the breast blackish; all beneath, except breast, white. Turning to the Key, the first direction is, to determine the "color-list" to which the bird belongs. Those birds that show neither black, yellow, blue, nor red, are in the "neutral list;" those with black (with or without red), but no yellow, are in the "black list;" those with yellow, but no black, in the "yellow list;" those with black and yellow, in the "black and yellow list;" and those with blue or red (without black or yellow), in the "blue or red list." Our bird in question is evidently in the "black list," on page r6. There are four of these black lists, belonging respectively to the four seasonal groups-Summer, Migrant, Winter, and Permanent, expressed by the first letter of each group, (S) (M) (W) (P). In which of these shall we look for our black and white specimen? The directions at the beginning of the Key tell us at once, where it says : "At different seasons of the year consult the four (season) groups contained in each (color) list, in the following order, and the species sought will generally be found in the first or second group of each series." We are supposed to have found the bird in winter, and a little farther on we find-_"Nov. I to April I, Permanent, Winter, Summer, Migrant." We are therefore likely to find our specimen in the Permanent or in the Winter Group under "Black Lists." Referring thereunder to (P), we see that Nos. $231-242$ comprise all that have black, 
but no yellow nor red. Immediately below, these are subdivided-"Nos. $23^{1-2} 3^{8}$ : black throughout, or with conspicuous black head-markings." It cannot be here. The next subdivision says, "Nos. 239-242 : no evident black on head." Not here. The next subdivision says, "Nos. 243-250: showing black and red, but no yellow." It is not here. Therefore we turn to the next group, according to direction-the Winter group-and we read: "Nos. I87-194: showing black, but no yellow nor red." As this accords, we turn to No. I 87 , and read the summarized description of that and of succeeding numbers. Going rapidly through the list, nothing agrees until we reach "I9I: Snow-bird: slaty black-black and white." All the details agree perfectly, and, with only the color to guide us, we have learned the name and principal life-habits of the species. If all the details of color (and in very many cases if only the principal details) are noted, there is not a single species belonging to the entire area that cannot be traced to its proper number through this Key. And even if one has failed to see some characteristic color that is inconspicuous, it has been so arranged that he may proceed upon his false assumption, and he will be led up to the same name as though he had seen every detail. At first glance it might seem that the amount of subdivision in the Key would make it intricate and more difficult to use. On the contrary, it will be found to simplify rather than to complicate the labor, by enabling one to trace every name with the greatest possible directness. After its use 
has been mastered, the majority of species, when fairly seen, can be identified in a few minutes.

To identify a bird by this or by any other method, it is of course necessary to have a distinct view of it, and to note its chief markings, which are commonly on head and breast. WVing-bars and tail-spots are also sometimes diagnostic; learn to estimate its approximate length, using for standards of measurement the crow ( 20 inches), robin (ro inches), and English sparrow (6 inches). Observe the bird in as many different positions as possible, and from the sunwuard side; and, first of all, become perfectly familiar with the different areas of a bird's body, as illustrated in the following charts.

With a good opera-glass the characteristic marks of even the smallest specimens can be clearly seen; and the use of a glass has the additional advantage of giving a good view at much longer range, whereby the birds are not frightened, and can be observed longer.

N. E. means New England States ; N. Y., New York; N. J., New Jersey; Pa., Pennsylvania; "northern edge" means the northern part of Maine, of New Hampshire, and of Vermont, with the Adirondacks (Ad'r'ks) of New York; "southern edge," the southern boundaryline of Pennsylvania and of New Jersey; S. E. N. Y., southeastern New York, where Alleghanian and Carolinian faunas join; "above" means the bird's upper side, including wings and tail; "below," its under side; $\delta$ is the usual sign for male; $q$ for female; figures always refer to a bird's proper number, under 
which it is described, and not to a page, unless so stated.

The color of the bill is not diagnostic, except where it is involved in the name of the bird (as black-billed and yellow-billed cuckoos), or where it is very large and conspicuous, as in the sea-swallow.

The following list comprises only those that are normally found within the territory, as regular summer or winter visitants, as migrants, or as permanent species. The book would only be enlarged, and its helpfulness would not be materially increased, by inserting those that occur only casually and at long intervals, as stragglers from the far west or south. It is possible that a very few species here given, whose exact status it is difficult to learn, should be regarded as casual rather than normal.

As a fact of interest to the more advanced ornithologist, it may be said that the various areas in which every species may be looked for at different seasons of the year have never before been so fully presented as in this book, in the descriptive details taken in connection with the several supplementary lists at the close of the four great Groups.

Acknowledgments are due, for such data as personal observation could not furnish, to W. A. Stearns's “ New England Bird Life" (edited by Dr. Elliott Coues), Minot's "Land and Game Birds of New England," Merriam's "Birds of the Adirondack Region" (Bull. N. O. C., VI.), Gilbert's “The Rarer Birds of Western 
New York" (Forest and Stream, VII.), Fowler's "Birds of Central New York" (Forest and Stream, VI., XII.), Warren's voluminous "Birds of Pennsylvania," Stone's "Birds of Eastern Pennsylvania and New Jersey," and Dr. Coues's great work, "Key to North American Birds." 



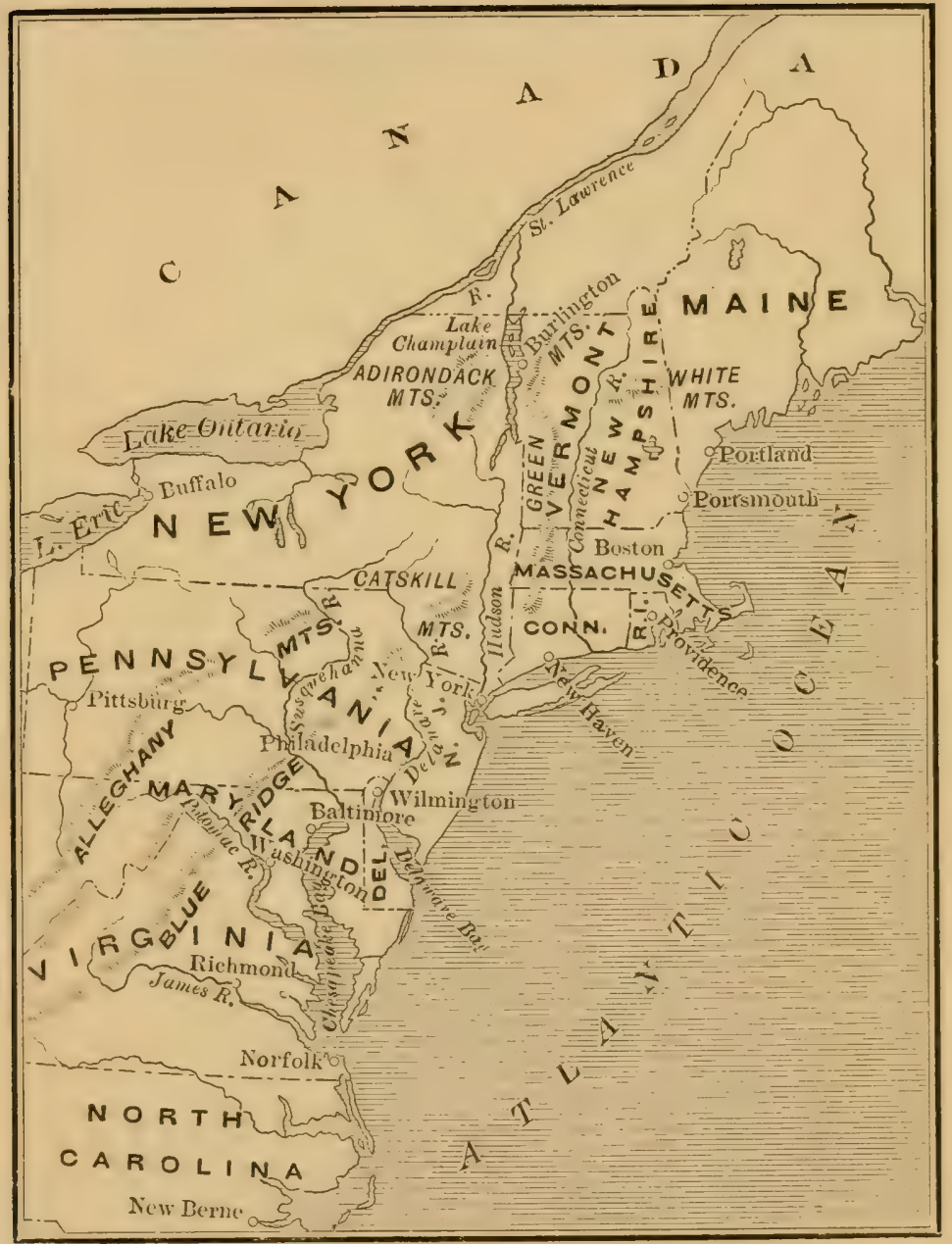

Map showing area expressly covered by this book, which is also essentially accurate for all the Eastern and Middle States. 

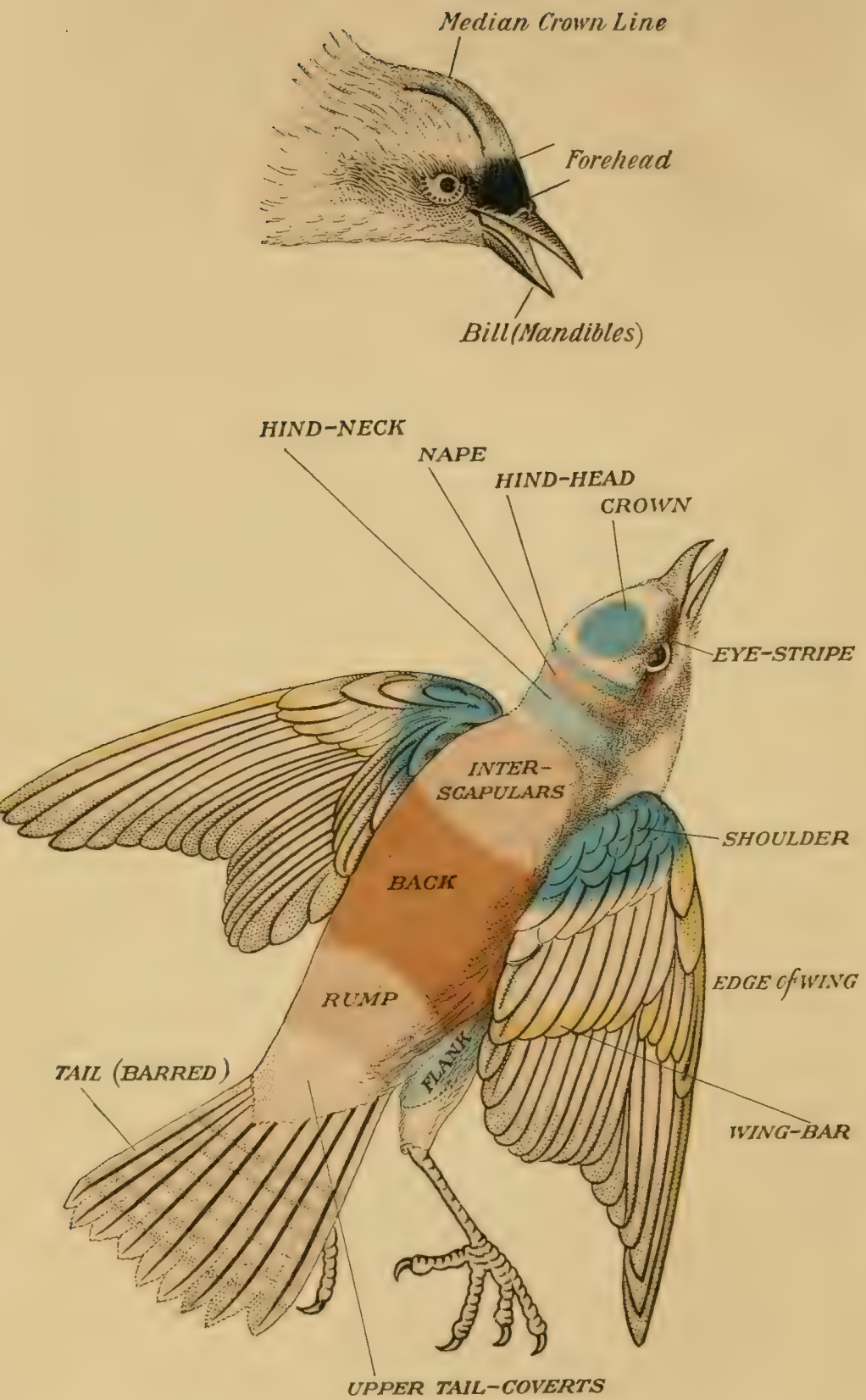

DISTINCTIVE AREAS OF A BIRD'S BODY.

N. B.-Unless otherwise specified, back includes interscapulars and rump. 

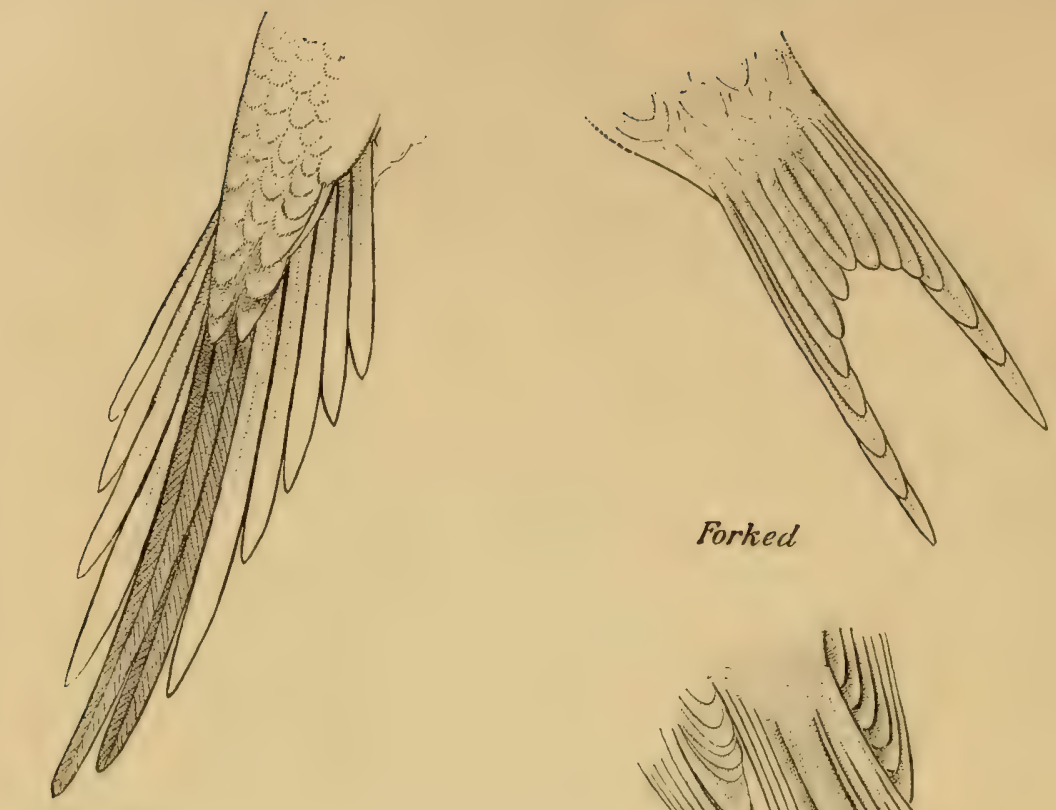

Graduated

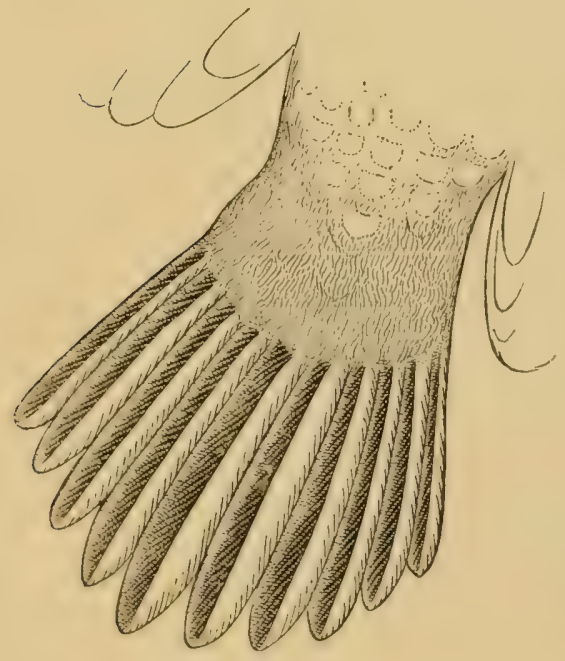

Rounded

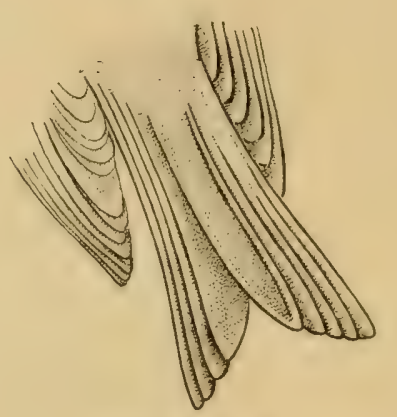

Emarginate

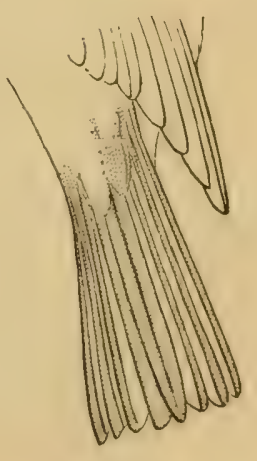

Square

VARIOUS FORMS OF TAIL. 


\section{ANALYTICAL KEY}

To find any land-bird-except " a bird of prey," Nos. 275-302, or a permanent "game-bird," Nos. 259-263-first determine to which of the five following (color) Lists it belongs. At different seasons of the year consult the four (season) Groups contained in each List, in the following order, and the species sought will generally be found in the first or second group of each series. (The dates and series of Groups are approximately correct for the whole territory. A very few species of summer and migrant birds arrive in March, especially in southern part of territory.)

\section{April I to June I,}

Summer, Migrant, Permanent, Winter.

June I to September I,

Summer, Permanent, Migrant, Winter.

September I to November I,

Summer, Migrant, Permanent, Winter.

November I to April I,

Permanent, Winter, Summer, Migrant.

The list of " occasional " species (occurring out of proper season), found at the end of each Group, should be reserved until the Group is reached to which they properly belong. Thus, April I-June I, the Summer, Migrant, and Permanent Groups should be examined before the "list of winter birds occasionally found in summer," which is at the end of Summer Group.

The groups are indicated by the first letter of each name: (S) Summer, (M) Migrant, (W) Winter, (P) Permanent. 


\section{$\left\{\begin{array}{l}\text { APRIL I TO JUNE I, (S), (M), (P), (W). } \\ \text { JUNE I TO SEPT. I, (S), (P), (MI), (WW) }\end{array}\right.$ \\ NEUTRAL LISTS. $\quad\left\{\begin{array}{l}\text { JUNE I TO SEPT. I, (S), (P), (MI), (W). } \\ \text { SET. I TO NOV. I, (S), (Mi), (P), }\end{array}\right.$ Nov. I TO APRIL I, (P), (W), (S), (W).}

Showing no Black, Yellow, Blue, nor Red.

(S) Nos. 1-29.

* Nos. 1-9 : Breast whitish, dark-spotted or streaked.

* * Nos. 10-20: Above, brownish or variegated; below (except Nos, 12 and 13), not spotted.

* * Nos. 21-29: Above, somewhat olivaceous.

(M) Nos. 149-155: All but the last two have breast dark-spotted. (W) Nos. 180-186.

(P) Nos. 227-230.

BLACK LISTS.

$$
\left\{\begin{array}{l}
\text { JUNE I TO SEPT. I, (S), (P), (M), (W). } \\
\text { SEPT. I TO NOV. I, (S), (M), (P), (W). } \\
\text { Nov. I TO APRIL I, (P), (W), (S), (M). }
\end{array}\right.
$$

Showing Black, but no Yellow.

(S) If Nos. 30-55: Showing black, but no yellow NOR RED.

† Nos. 30-39: Above and below, quite or nearly alike.

Nos. 30-34: Entirely or $(32,34)$ nearly black throughout.

No. 35 : Slate, with black crown and tail.

Nos. 36, 37: Ashy gray above, white or whitish below.

Nos. 38, 39: Prevalent blue.

$\dagger+$ Nos. 40-55: Above and below not uniform.

* Nos. 40-44: Head black-striped.

* * Nos. 45-55: Head not black-striped.

† Nos. 45-49: Entire under side white (whitish) or black.

$t+$ Nos. 50-55: Entire under side not white nor black.

II Nos. 56-70: Showing black AND RED, but no yellow.

* Nos. 56-64: Red on breast.

* * Nos. 65-70: No red on breast. 
(M) I Nos. 156-161: Showing black, but no yellow NOR RED. II IT Nos. 162-164: Showing black AND RED, but no yellow. (W) I Nos. 187-194: Showing black, but no yellow NOR RED. I I Nos. 195-199: Showing black AND RED, but no yellow. (P) If Nos. 231-242: Showing black, but no yellow NOR RED. * Nos. 231-238: Black throughout, or with conspicuous black head-markings.

* Nos. 239-242: No evident black on head.

I I Nos. 24.3-250: Showing black AND RED, but no yellow.

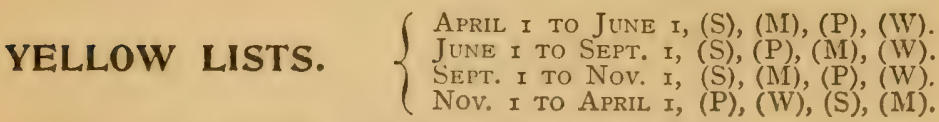
Showing Yellow, but no Black.

(S) Nos. 71-86.

* Nos. 71-77: TVith bright yellow on throat and breast.

* Nos. 78-86: Without bright yellow on both throat and breast (or on neither).

(M) Nos. 165-167.

(W) None.

(P) No. 251.

BLACK AND YELLOW $\int$ APRIL I TO JUNE I, (S), (MI), (P), (W).

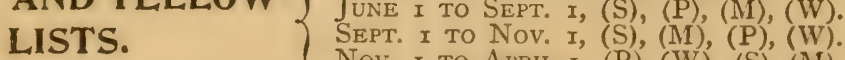
Nov. I to Arril I, (P), (W), (S), (M).

Showing both Black and Yellow.

(S) Nos. 87-106.

* Nos. 87-92 : Black and yellow on breast.

* Nos. 93-97: Breast pure yellow (or (97) black bordered).

* * Nos. 98-106: No yellow on breast.

(M) Nos, 168-175.

* Nos. 168-172: Throat and breast black (or ashy) and yellow, or pure yellow. 
* Nos. 173-175: Throat scarlet or white.

(W) Nos. 200-202.

(P) Nos. 252-257.

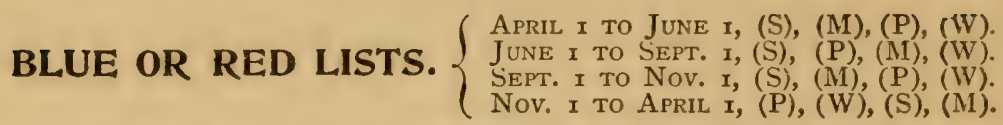
Showing one or both of these Colors, but no Black nor Yellow.

(S) Nos. 107-118.

(M) Nos. 176, 177.

(W) Nos. 203-205.

(P) No. 258.

RED LIST OF LAND AND WATER BIRDS, in classified order, pp. 99-102.

PERMANENT GAME BIRDS.

Nos. 259-263.

\section{SPARROW LIST.}

Nos. $6,7,8,68,69,70,79,81,105,106,152,158,173,183$, $198,241,250(273,274$, only migrant on N. J. coast).

\section{BIRDS FOUND ONLY IN N. Y., PA., OR N. J.} Nos. 264-274.

\section{WATER BIRDS.}

(S) Nos. 119-148: In subgroups according to habitat.

(M) Nos. 178, 179: Having inland migration.

(W) Nos. 206-226.

* Nos. 206-209: The commonest on coast and in interior in winter. 
* * Nos. 210-226: Regularly and not uncommonly on coast, and on larger rivers of $\mathrm{Pa}$. and N. J., in winter.

\section{LISTS OF OCCASIONAL SPECIES,}

normal to territory, but found out of proper season.

Winter birds found regularly or occasionally in summer; p. 53 .

Summer and Migrant birds occasionally found in winter; p. 82 .

\section{SPECIAL LISTS FOR PA. AND N. J.}

Summer birds that are only Migrant in Pa. or N. J. ; p. 72. Summer and Migrant birds that are permanent in $\mathrm{Pa}$. or $\mathrm{N}$. J. ; p. 96.

Summer and Migrant birds found (in winter) only in Pa. or N. J. ; p. 82 .

Migrant birds found regularly or occasionally in summer in $\mathrm{Pa}$; p. 54.

\section{BIRDS OF PREY.}

EAgLeS-Nos. 275, 276.

Hawks (and Allies)-Nos. 277-291.

OWLS-Nos. 292-302.

In the following species the sexes have little or no resemblance. (Proper number precedes, length follows, the name.)

65. Red-winged Blackitrd; 9.

195. Pine Grosbeak ; 8-9.

59. Rose-BREASTED GROSBEAK; $8-8 \frac{1}{2}$.

67. Towhee Bunting; $8-81 / 2$.

88. BALTIMORE ORIOLE; $7 \frac{1}{2}-8$.

114. Summer TANager; $71 / 2-8$.

61. Scarlet Tanager; $7 \frac{1}{2}$. 
49. ВовоLiNK; $7 \frac{1}{2}$.

32. COW-BIRD; $71 / 2$.

62. ORCHARD ORIOLE; 7 .

38. Blue Grosbeak; $61 / 2-7$.

115. Purple Finch; 6.

196. Common Crossbill; 6.

197. White-Winged Crossbill; 6 .

39. INDIGO-BIRD; $5 \frac{1}{2}$.

63. REDSTART ; 5\%/4.

161. Black-throated Blte Warbler; 5 .

256. AMERICAN GOLDFINCH; $43 \% 4$. 


\section{SUMMER GROUP.}

\section{LAND-BIRDS.}

Comprising those species that arrive from the south in spring, breed more or less generally throughout the territory, and retire southward in the fall. The earliest arrivals are about the middle of March, and the latest departures about the end of October.

\section{NEUTRAL LIST.}

Nos. 1-29. Showing no Black, Yellow, Blue, nor Red. * Nos. 1-9: Breast whitish, dark-spotted or streaked.

\section{THRASHER : BROWN THRUSH.}

\section{Tawny-Whitish, dark-spotted.}

I I. Wings, white-barred; tail, quite long; below, whitish, thickly marked with brown, except on throat, rear, and under tail-coverts.

Nest, more or less of sticks, cedar-bark, dead leaves, etc., in bush or on ground; eggs, last of May, 4-5, whitish or greenish, thickly brown-speckled ; song, incoherent, like cat-bird's.

\section{WOOD THRUSH : SONG THRUSH.}

Tawny-Whitish, dark-spotted.

71/2-8. Above, forepart soft reddish-brown, becoming olive on rump, tail, and end of wings; below, white, buff-tinged 
on breast; breast and sides, strongly spotted with dark brown.

Abundant from southern edge to Mass. ; nest, of grass, twigs, moss, with inner layer of mud lined with rootlets, not far from ground; eggs, latter part of May, 4-5, greenish-blue ; fine singer.

\section{WILSON'S THRUSH : VEERY.}

\section{Tawny-Buff-white, spotted.}

7-7 $1 / 2$. Above, tawny throughout; throat and breast, buff-white, breast faintly spotted with light brown; sides and abdomen, white.

From northern $\mathrm{mts}$. of $\mathrm{Pa}$. and northern part of $\mathrm{N}$. J. northward ; rare on northern edge, locally common in Ad'r'ks; winters rarely in S. Pa. ; nest, of grass, leaves, roots, etc., without mud, usually on ground; eggs, latter part of May, 4-5, light greenish-blue; good singer.

\section{LOUISIANA WATER THRUSH.}

Dark olive-brown —-Whitish, dark-spotted.

6. Superciliary line, whitish; below, throat and rear, pure white; rest, buff-tinged (never sulphury-yellow), sparsely spotted with pale brown.

North to southern Conn. (and in southern Ad'r'ks); rarely beyond, very rare in N. J. ; habits, nest, and eggs, as in $\mathbf{5}$.

\section{WATER THRUSH: WATER WAGTAIL.}

Dark olive-brown-Whitish, dark-spotted.

$5^{1 / 2}-6$. Superciliary line, whitish; below, whitish, or pale sulphury-yellow, sharply and thickly spotted, except on rear.

Nest, on or near ground, in damp places, or near water ; eggs, carly in June, 4-6. white, spotted with brown and lilac; walks, with teetering tail; fair singer; in N. J. only migrant. 


\section{VESPER SPARROW: GRASS FINCH.}

Grayish-brown, dark-streaked-White, streaked.

6. No median crown-line; whitish superciliary line and eye-ring; patch on wing, chestnut; outer tail-ficathers, white; below, white, often buffy; breast and sides, darkstreaked.

Nest, on ground; eggs, latter part of May, 4-5, diversely colored; in open fields, by roadsides, etc. ; a pleasing singer ; winters rarely in S. Pa. and N. J.

\section{\%. SHARP-TAILED SPARROW.}

Olive-brown, streaked—Brownish-white, streaked.

$5^{\mathrm{T} / 2}$. Light median crown-line; long superciliary line, rich buff or orange-brown ; breast, strongly dark-streaked.

In salt marshes of sea-coast; nest, in tussock of grass by water; eggs, grayish white, evenly spotted; abundant species.

\section{LINCOLN'S SPARROW.}

Grayish-brown, streaked - Whitish, streaked.

$5 \frac{1}{2}$. Crown darker, with median and lateral ashy stripes; below, white, with distinct brownish-yellow band across breast, sides tinged with same; entire under side, except abdomen, dark-streaked.

From Conn. northward; rather rare ; nest, on ground; eggs, about May Ist, $4-5$, color variable; sings freely.

\section{HENSLOW'S SPARROW.}

Buff-brown, dark-streaked-Buff-whitish, streaked.

\section{See $\mathbf{1 0 5}$.}

* Nos. 10-20: Above, brownish or variegated; belowe (except Nos. 12 and 13), not spotted. 


\section{BLACK-BILLED CUCKOO.} Brownish-gray - White.

II-I2. See 45.

\section{YELLOW-BILLED CUCKOO.}

Brownish-gray - White.

I I-I2. See 98.

\section{WHIPPOORWILL.}

Mottled with various quiet colors.

9 $1 / 2$. Prevailing tone, grayish-brown, from mingling of black, gray, and reddish-brown; end of outer tail-feathers, white ; tail, rounded; throat, white; $q$ has throat and tips of tail-feathers tawny.

No nest; about June Ist 2 eggs are laid on ground or in a depression, creamy, spotted variously ; a nocturnal species.

\section{NIGHT-HAWK.}

Mottled with various quiet colors.

9. General appearance same as of whippoorwill; white patch on wing; tail, cmarginate and white-spotted.

No nest; about June Ist 2 eggs are laid on ground, rock, or flat roof, variable in tints and markings; seen mostly high in air at dusk, early evening, or in cloudy day; booming sound at dusk in June.

\section{FIELD SPARROW.}

Light brown, dark-streaked-Brownish-white. $5 \%$. See 70 .

\section{GREAT CAROLINA WREN.}

Reddish-brown-Rusty-white.

$51 / 2-6$. Long, prominent, whitish superciliary line ; wings and tail, dark-barred.

A southerly species ; rarely north to Mass. ; " permanent" in Pa. and N. J. ; nest, of various materials, in hole, nook of building, or shrubbery ; eggs, 6-7, white, spotted with various tints. 


\section{LONG-BILLED MARSH WREN.}

\section{Brown-Brownish-white.}

5-51/2. Above, brown, unbarred; crown, dark; whitish superciliary line; middle of back, black, white-streaked; tail (and wings somewhat), barred; below, central part of breast nearly white; deeply shaded with brown on sides.

North to Mass. ; nest, of woven rushes and mud, lined with hair, attached to waving reeds; eggs, last of May, 6-1o, dark chocolatebrown; fine architect; in fresh and salt marshes; somewhat grega. rious; winters rarely in S. N. J.

\section{SHORT-BILLED MARSH WREN.}

\section{Brown-Brownish-white.}

4\%2. Above, blackish-brown, white-streaked; whitish superciliary line; tail (and wings somewhat), barred.

Mass. and southward; rare in $\mathrm{Pa}$. ; only rare migrant in $\mathrm{N}$. J., where it occasionally winters in southern part ; nest differs from that of "long-billed" in being without mud, and sometimes in tussock of grass ; eggs, last of May, 6-8, white, unmarked; somewhat gregarious.

\section{HOUSE WREN.}

\section{Dark wren-brown —Light brown.}

$4^{1 / 2}-5^{1 / 2}$. Obscure superciliary line; finely waved throughout with blackish-brown; tail, erect.

Nest, of miscellaneous materials, in hole; eggs, June Ist, 6-9, pinkish-white, speckled throughout ; fine singer.

\section{BANK SWALLOW.}

\section{Dull brown — White.}

5. Band across breast, dull brown.

Nest, a horizontal hole in sand-bank, about $2 \mathrm{ft}$. deep, enlarged at inner end, which is lined with soft material ; eggs, latter part of May, 4-5, pure white. 


\section{ROUGH-WINGED SWALLOW.}

\section{Dull brown—Whitish.}

5. Darker across breast; differs from bank swallow in having a series of hooks on outer web of first wing-feather, serrate in appearance, invisible at distance.

Nest, not in sand-bank, but in cavities of fence, house, and the like ; eggs, 4-6, pure white; apparently rare.

*** Nos. 21-29: Above, somezohat olivaceous.

\section{OLIVE-SIDED FLYCATCHER.}

\section{Dark olive-brown - Whitish, streaked.}

$7 \%$. Upper mandible, black; lower, yellowish; crownfeathers, erectile and darker ; wings and tail, darker ; tail, emarginate; below, breast peculiarly streaked with olivebrown tint; remainder, including middle line of breast, white or yellowish.

Breeds from Conn. northward; nest, unpretentious, at quite a distance from ground; eggs, early in June, 5, white, or whitish, spotted.

\section{PHCEBE.}

Dull olive-brown - Whitish.

7. Bill, all black; crown-feathers, erectile and darker; tail, emarginate; below, white, clouded with tint of upper side.

Quite generally distributed; nest, under eaves, and in similar places, prettily made of grass and mud, stuccoed with moss, and lined; often 3 broods; eggs, early in May, 5, usually pure white; constantly firts tail; an early spring arrival.

\section{PEWEE.}

Olive-brown - Light ash.

6-6 $1 / 2$. Wings and tail, darker; see 51. 


\section{ACADIAN FLYCATCHER.}

\section{Olive-green —Whitish.}

$53 / 4-61 / 4$. Crown-feathers, erectile and darker; yellowish eye-ring ; wing-markings, yellowish-white ; breast, clouded with tint of upper side, but interrupted by middle whitish line; posterior part, below, washed with yellow.

Rarely north to Conn. ; nest, in trees; eggs, 2-4, creamy white, strongly marked.

\section{TRAILL'S FLYCATCHER.}

\section{Olive-green-Ashy.}

$5 \% 2-6$. Crown-feathers, erectile and darker; wing-bars, gray; breast, entirely shaded with olive-gray.

Breeds from Conn. northward; nest, near ground, in damp places; eggs, 2-4, creamy white, strongly marked; note, ké-wink, uttered slowly.

\section{LEAST FLYCATCHER. Olive-green-Ashy.}

$5-5 \frac{1}{2}$. Crown-feathers, erectile and darker; wing-bars, gray; breast, clouded with olive-gray.

Particularly abundant in N. E. ; nest, in tree ; eggs, early in June, 4-5, pure white, rarely spotted; note, se-zici, uttered quickly.

\section{SOLITARY VIREO: BLUE-HEADED VIREO.}

\section{Olive-green - White.}

$5 \frac{1}{2}$. Head, bluish ash; eye-ring and line to bill, white; 2 white wing-bars; sides, olive-shaded; under tail-coverts, slightly yellow.

Generally distributed, but more abundant in northern than in southern N. E., and only migrant in N. J. ; nest, pensile and artistic, not far from ground; eggs, about June Ist, $3-4$, white, with fine reddish dots. 


\section{WARBLING VIREO.}

\section{Mouse-color — White.}

5. Whitish superciliary line; below, sides tinged with shade of back.

Nest, pensile, higher than "red-eye's," "from 20 to $60 \mathrm{ft}$." in poplar, elm, or buttonwood tree; eggs, about June Ist, 4-5, white, brown-spotted; found especially in trees along roadway ; a wayside warbler.

\section{PHILADELPHIA VIREO.}

Mouse-color - White.

Indistinguishable, at field-range, from warbling vireo; differs in having extra quill in wing, and somewhat distinct song; in $\mathrm{Pa}$. and $\mathrm{N}$. J. it is only a rare migrant.

\section{BLACK LIST.}

I Nos. 30-55: Showing black, but no yellore NOR RED.

+ Nos. 30-39: Above and below quite or nearly alike.

Nos. 30-34: Entirely or $(32,34)$ nearly black throughout.

No. 35 : Slate, with black crown and tail.

Nos. 36, 37 : Ashy gray above, white or whitish below.

Nos. 38, 39 : Prevalent blue.

\section{FISH CROW.}

\section{Black.}

14-16. Like common crow, but smaller.

Along coast, north to Conn., rarely beyond; along larger rivers of Pa. ; nesting like common crow (23:); pisciverous. 


\section{PURPLE GRACKLE: CROW BLACKBIRD.}

\section{Iridescent black.}

I2-I3. Iridescent with green and purple; eye, creamy; o smaller, blackish-brown, and more or less lustrous.

Breeds throughout, but more abundant northerly; gregarious; nest, large and coarse, commonly with mud, in bush or tree, the latter usually evergreen; eggs, latter part of May, 4-5, very variable ; one of first to arrive in spring; winters rarely in S. Pa. and S. N. J.

\section{COW-BIRD: COW BLACKBIRD. \\ Iridescent black.}

$7 \frac{\pi}{2}$. Head and neck, dark chocolate; + , smaller, brown throughout, lighter below.

Polygamous, parasitic, and gregarious; eggs, laid in nests of other birds from April on, probably 4-5, apparently irregularly, white, finely speckled with brown and pale lilac.

\section{PURPLE MARTIN.}

\section{Lustrous blue-black.}

7. \& Duller above, somewhat whitish below, with darkgray streaks.

Nest, formerly in tree-holes, now in boxes, etc., like white-breasted swallow; eggs, $4-5$, in May, pure white.

\section{CHIMNEY SWIFT : CHIMNEY SWALLOW.}

\section{Blackish (sooty brown).}

5. Throat, gray ; wings, black; below, lighter.

Nest, of twigs glued together with the bird's saliva, and attached to interior of chimneys; remote from human habitation it nests in hollow trees, where possibly it sometimes hibernates! eggs, 4, pure white. 


\title{
35. CAT-BIRD.
}

\author{
Slate, black-Slate.
}

$8 \frac{1}{2}-9$. Crown and tail, black; see $\mathbf{6 6 .}$

\section{MOCKING-BIRD.}

Ashy-gray - White.

9-1o. Wings and tail, blackish, conspicuously spotted with white; outer tail-feathers, pure white.

A southern species, rarely summering in Northeastern States, and has been found there in winter; nest, clumsy, not far from ground; eggs, 4-6, bluish-green, thickly spotted.

\section{3\%. LOGGERHEAD SHRIKE.}

\section{Ashy-gray-Whitish.}

8-9. Forehead, black, continuous with black stripe through eye; wings and tail, black, white-spotted; below, white, clouded, but not "waved," as in butcher-bird (187).

A southern species, but locally in $\mathrm{Pa}$. and $\mathrm{N}$. J., and very rarely breeding north to N. E. ; nest, simple ; eggs, like those of butcherbird.

\section{BLUE GROSBEAK.}

\section{Dark blue and black.}

$61 / 2-7$. Around base of bill, wings, and tail, black; 2 chestnut wing-bars; $q$, smaller, brown above, lighter below, brownish-white wing-bars.

Breeds sparingly in S. Pa., north of which it is possibly only a straggler; no record in N. J. ; nest, in bush or low tree; eggs, 4-5, pale blue, unspotted. 


\section{INDIGO-BIRD.}

\section{Indigo-blue and blackish.}

$5 \frac{1}{2}$. Blue most intense on head; wings and tail, blackish; o brown above, lighter below, slightly streaked.

Breeds throughout, rarer north of Mass.; nest, rather large, in bush ; eggs, last of May, 4-5, white or blue-tinged, rarely marked.

It Nos. 40-55: Above and below not aniform.

* Nos. 40-44: With head black-striped.

\section{RED-EYED VIREO.}

Olive-green - White.

6-6 $1 / 2$. Crown, ashy, edged with black stripe; whitish superciliary line; dark eye-stripe; red eye; below, sides yellow-shaded.

Nest, pensile, often showing pine-needles, pieces of paper and of wasp's nest ; eggs, about June Ist, 3-5, pure white, red-tinged and spotted at larger end; a bright song throughout summer in woods.

\section{OVEN-BIRD: GOLDEN-CROWNED THRUSH.}

Rich olive-White, dark-spotted.

$5 \frac{\pi}{2}-61 / 2$. Crown, buff-orange, bordered with black; throat, white; breast, blackish-spotted.

Nest, on ground, of leaves and grasses, lined with hair, roofed over; eggs, about June Ist, 4-6, cream-white, marked; walks on ground.

\section{WORM-EATING WARBLER.}

Greenish-olive-Buff.

$5^{\mathrm{x} / 2}$. Head, buff, and with 4 black stripes, 2 bordering crown, 2 through eyes; rear, whitish.

North rarely to Conn., in $\mathrm{N}$. J. chiefly in southern part; nest, on ground; eggs, 4-5, pure white, finely spotted. 


\section{BLACK-AND-WHITE CREEPER.}

Black, streaked with white.

5-51/4. Top of head, black-and-white striped; below, whiter than above.

Nest, of grass, leaves, moss, delicately lined; eggs, about June Ist, $4-6$, creamy white, dark-spotted; always creeping on trunk and branches.

\section{BLUE-GRAY GNAT-CATCHER.}

\section{Ashy-blue —White.}

4 $1 / 2-5$. Forehead and superciliary line, black; tail, black and white (outermost feathers entirely white) ; + head without black.

North to S. E. N. Y. and in western N. Y; rare, except locally ; nest, elegant, covered with lichens, cup-shaped, Io- $60 \mathrm{ft}$. from ground; remarkably active and voluble.

* Nos. 45-55: Without black stripe on head.

† Nos. 45-49: Entire under side white (whitish) or black.

\section{BLACK-BILLED CUCKOO.}

Brownish-gray-WWite.

II-I2. Bill, black; eye-ring, red; outer tail-feathers, white-tipped (subtipped with black); breast, sometimes slightly tinged with light brown.

Throughout, but the more northerly of the two species; nest, rather crude, not far from ground; eggs, early in June, $4-8$, greenish, laid irregularly.

\section{YELLOW-BILLED CUCKOO.}

Brownish-gray —White.

II-12. Bill, largely ycllow; see 98 . 


\section{KING-BIRD : BEE-MARTIN.}

Blackish-gray-White.

8. Crown, black, with erectile feathers, tipped with orange (seldom seen at field-range); wings, slightly brown; tail, black, broadly white-tipped; breast, cloudy.

Nest, rather large and compact; eggs, about June Ist, 4-6, white, creamy, or rosy, variously marked; on telegraph-wires and similar conspicuous places.

\section{7a. PHEBE.}

Dull olive-brown - Whitish.

7. Blackish crown; see $\mathbf{2 2 .}$

\section{WHITE-BREASTED SWALLOW.}

\section{Lustrous dark green, blackish_-White.}

6. Wings and tail, blackish; otherwise, above, lustrous green.

Nest, in martin-box, or similar cavity, rarely in tree-hole ; eggs, 45, pure white.

\section{BOBOLINK : RICE-BIRD.}

\section{Black and white-Black.}

$7 \frac{1}{2}$. Hind neck, buff; shoulders, rump, and upper tailcoverts, white ; middle of back, streaked; otherwise, black ; $q$, above, yellowish-brown, dark-streaked, wings and tail dark; median and superciliary lines and under parts, brownish-yellow.

Breeds throughout, less common in $\mathrm{Pa}$., only migrant in $\mathrm{S}$. N. J. ; nest, on ground, in field or meadow; eggs, latter part of May, 4-5, white, variously tinged and spotted ; eccentric, beautiful in plumage and song.

$\dagger+$ Nos. 50-55: Entire under side neither white nor black. 


\section{BELTED KINGFISHER.}

Ashy-blue, black —Blue, white.

$12 \%$. Crested; see $10 \%$.

\section{0a. UPLAND PLOVER.}

Blackish, variegated-Pale rufous, black-streaked.

12. A water-bird; see 119.

\section{0b. WHIPPOORWILL.}

Mottled with black, gray, and reddish brown.

$9 \frac{1}{2}$. See 12.

\section{0c. NIGHT-HAWK.}

Mottled with quiet colors.

\section{See 13.}

\section{0d. OLIVE-SIDED FLYCATCHER.}

Dark olive-brown - Whitish, streaked.

$71 / 2$. Crown, wings, and tail, blackish; see $\mathbf{2 1}$.

\section{PEWEE.}

Olive-brown — Light ash.

$6-6 \pi / 2$. Crown feathers, erectile and darker; wings and tail, blackish ; 2 white wing-bars ; tail, emarginate; below, throat and abdomen dull yellowish-white ; breast and sides, clouded with tint of upper side.

Nest, artistic ; eggs, middle of June, 4-5, buff or creamy, with large spots of lilac and reddish-brown; note, pe-u-wee or pe-wee.

\section{FIELD SPARROW.}

Light brown, black-streaked, crown reddish_-Brownish$5 \frac{1}{2}$. See 70 . white. 


\section{SHARP-TAILED SPARROW.}

Olive-brown, streaked-Brownish-white, blackish-streaked. $5 \mathrm{~T} / 2$. See 7 .

\section{3a. LINCOLN'S SPARROW.}

Grayish-brown, streaked-Whitish, dark-streaked. $5 \% 2$. See 8.

\section{HENSLOW'S SPARROW.}

Buff-brown, black-streaked-Buff-white, streaked. 5. Crown, blackish; edge of wing, yellow; see $\mathbf{1 0 5}$.

\section{4a. LONG-BILLED MARSH WREN.}

Brown-Brownish-white.

5-5 $\frac{1}{2}$. Crown and interscapulars, blackish; see $\mathbf{1 6 .}$

\section{SHORT-BILLED MARSH WREN.}

Brown-Brownish-white.

$4^{1 / 2}$. Crown and back, blackish; see $\mathbf{1 7}$.

\section{4c. HOUSE WREN.}

Dark wren-brown - Light brown.

$4^{1 / 2}-5^{\mathrm{T}} / 2$. "Waved" with blackish; see 18.

\section{CERULEAN WARBLER.}

Azure-blue, black-streaked-White, blue-streaked.

$4 \frac{1}{2}$. Bill, black; wings and tail, blackish; 2 white wingbars; nearly all tail-feathers white-spotted; below, pure white, except blue-black streaks on breast and sides.

Breeds occasionally in mts. of Pa. and northward to S. E. N. Y.; in N. J. only a rare migrant ; nest, delicate, 20-50 ft. from ground ; eggs, 4, creamy-white, strongly marked with reddish-brown; a rare and beautiful species. 
I I Nos. 56-70: Showing black AND RED, but no yellow.

* Nos. 56-64: With red on breast.

\section{MOURNING DOVE.}

\section{Grayish-blue-Purplish-red.}

12. Bill, black; eye, red; black spot on side of head; neck, iridescent ; shoulders, black-spotted; ends of wings and middle tail-feathers, black; outer tail-feathers, black and white; throat and breast, purplish-red; abdomen, lighter; sides, grayish-blue ; essentially like wild pigeon, but smaller; $q$ has red of breast replaced by grayish.

Breeds northward to southern edge of Mass. and on southern edge of Ad'r'ks, but found irregularly and in small flocks; sometimes seen in winter, and permanent in several counties of $\mathrm{Pa}$. and in S. N. J. ; nest, on ground or in bush; eggs, in May, 2, pure white.

\section{ROBIN.}

\section{Dark olive-gray — Bright chestnut.}

9-10. Bill, yellow; head, black, slightly white-spotted; tail, blackish, end of outer feathers, white; chin, white, black-streaked; throat, breast, and sides, bright chestnut; under tail-coverts, white.

Nest, of three layers, outside of coarse vegetable material, the middle of mud, finely lined, in all sorts of places, chiefly in trees; eggs, latter part of April, 4-5, greenish-blue; permanent in N. J.

\section{CARDINAL GROSBEAK.}

\section{Vermilion.}

$81 / 2$. Bill, coral red; black around base of bill; crested; $q$, very much faded.

Northward, rarely to Conn, permanent in S. Pa. and N. J ; nest, in bush or tree, near ground. often near water, rather coarse; eggs, white, brown-spotted; a favorite cage-bird. 


\section{ROSE-BREASTED GROSBEAK.}

\section{Black and white-Carmine and white.}

8-81/2. Head, entire neck, and interscapulars, pure black; rump, white; wings and tail, black, with white markings; brecust and under wing-coverts, rich rosy red; otherwise, below, white; carmine requires 2 or 3 years for perfection; \&, above, flaxen-brown ; below, white ; dark-streaked throughout; median and superciliary lines, whitish; dark eye-stripe; wings and tail, unmarked; breast, sometimes saffron.

Breeds in W. Pa., N. N. J., and northward, but rarer north of Mass. ; nest, in tree or shrubbery ; eggs, about June Ist, $3-4$, greenish, spotted; handsome and a fine singer.

\section{BALTIMORE ORIOLE.}

Black and orange.

$71 / 2-8$. See 88.

\section{SCARLET TANAGER.}

Scarlet and black-Scarlet.

$7 \% / 2$. Entirely scarlet, except black wings and tail; $q$, olive-green above, yellowish below.

Rather general, but not abundant, up to northern part of N. E. and in Ad'r'ks; nest, inartistic, in tree or thicket, not far from ground; eggs, latter part of May, 3-5, pale greenish-blue, thickly spotted; brilliant, but not very interesting.

\section{ORCHARD ORIOLE.}

Black and chestnut.

7. Entire head, neck, and back, black; rump and upper tail-coverts, chestnut; wings, black, white-barred; tail, black, with a little chestnut; below, throat and upper 
breast, black; otherwise chestnut; perfect plumage in 3 years; $\&$, above, olive-yellow, wings darker, whitishbarred; below, yellowish; smaller than 5 .

Breeds throughout, but rare in Mass. and northward; nest, less deep and pensile than that of Baltimore oriole; eggs, middle of June, 4-5, white, spotted.

\section{2a. CLIFF SWALLOW. Steel-blue, blackish_Chestnut.}

$5-5 \frac{1}{2}$. See 112.

\section{REDSTART.}

Glossy black, flame-spotted.

$5 \%$. Black throughout, except sides of breast, patches on wings, and basal half of tail, which are flame-colored; abdomen, white; $q$, greenish above, whitish below, pale yellow in place of flame-color of $\hat{o}$.

Nest, compact and well-made, in fork of low tree or bush; eggs, June Ist, 4-5, white, strongly spotted; has peculiar dash and vigor, with a characteristic sharp note.

\section{BLACKBURNIAN WARBLER.}

Black, white-marked-Orange.

$4 \frac{1}{2}$. See 97 .

* * Nos, 65-70: With No red on breast.

\section{RED-WINGED BLACKBIRD. \\ Black.}

9. Shoulders, scarlet, bordered by brownish-yellow to whitish ; otherwise iridescent black; + , smaller ; above, dark; below, whitish, thickly streaked.

Nest, in swamps, on ground or low bush ; eggs, middle of May, 4-5, pale blue, somewhat marked at larger end; in large flocks in spring and fall; winters in S. N. J. 


\section{CAT-BIRD. \\ Slate, black —Slate.}

$81 / 2-9$. Bill, crown, tail, and feet, black; under tail-coverts, chestnut-red; a little lighter below than above.

Nest, with coarse exterior, lined, in bush or thicket; eggs, latter part of May, 3-5, dark greenish-blue ; sings finely at times, but incoherently.

\section{6\%. CHEWINK: TOWHEE BUNTING.}

Black-Black, chestnut, white.

$8-81 / 2$. Eye, red; above, pure black; outer tail-feathers, mostly white; below, throat and upper breast, black; sides, chestnut; other under parts, white. of replaces black of fo with warm brown.

Breeds throughout, but rare north of Mass. ; in winter exceptionally in N. E., S. Pa., and N. J.; nest, on ground, often in clamp places; eggs, latter part of May, 4-5, white or tinged, finely spotted.

\section{6ya. KING-BIRD. \\ Blackish-gray_-White.}

8. Erectile crown-feathers, orange-tipped; see $\mathbf{4 \%}$.

\section{7b. OVEN-BIRD.}

Rich olive-White, dark-spotted.

$5 \frac{1}{2}-6 \frac{1}{2}$. Crown, buff-orange, black-bordered; see 41.

\section{SWAMP SPARROW.}

Brownish, black-streaked-Ashy.

$51 / 2-6$. Forehead, black ; crown, chestnut; sides of head, neck, and breast, ashy; below, chin and abdomen nearly 
white; breast, unspotted but faintly streaked, as are the brown-shaded sides.

Nest, in tussock of grass, or low in a bush, in swamps; eggs, middle of May, 4-5, white, variously tinged and spotted; found chiefly in secluded wet lands; has great variety of simple songs; winters in Pa. and N. J.

\section{8a. SHARP-TAILED SPARROW.}

Olive-brown, streaked-Brownish-white, streaked.

$5 \frac{1}{2}$. Superciliary line, rich buff; see $\boldsymbol{\%}$.

\section{CHIPPING SPARROW : HAIR-BIRD.}

\section{Reddish-brown, black-streaked-Ashy.}

$5 \% 2$. Bill and forehead, black; crown, chestnut; superciliary line, light; blackish eye-stripe; rump, ashy; 2 white wing-bars; tail, emarginate; no markings on ashy throat and breast.

Nest, of fine vegetable material, lined with horse-hair, in low tree, bush, or vine, seldom on ground; eggs, about June Ist, 4-5, light bluish-green, dark-spotted.

\section{FIELD SPARROW.}

Light brown, black-streaked-Brownish-white.

51/2. Bill, dull reddish; crown, rufous red; sides of head and neck, indefinitely marked with brown; 2 obscure whitish wing-bars.

Not plentiful northward beyond Mass. ; more southerly than chipping sparrow; nest, on ground or in low bush, in open land; eggs, late in May, 4-5, grayish-white, thickly spattered with light reddishbrown; pleasing but unpretentious singer; winters in $\mathrm{Pa}$. and $\mathrm{S}$. N. J. 


\section{YELLOW LIST.}

Nos. 71-86: Showing Yellow, but no Black.

* Nos. 71-77: With bright yellow on throat and breast.

\section{YELLOW-BREASTED CHAT.}

Bright olive-green-Rich yellow.

7. See 93.

\section{YELLOW-THROATED VIREO. \\ Olive-green-Yellow.}

6. Superciliary line and eye-ring, yellow; bluish-ash on rump; 2 white wing-bars; abdomen and under tail-coverts, white.

Rarely north of Mass.; common in Ad'r'ks ; nest, pensile and elaborate, several feet from ground; eggs, about June Ist, 4, white, spotted with various tints ; handsomest of vireos or " greenlets."

\section{PINE WARBLER.}

Olive-Yellow.

$5 \% 2-6$. Superciliary line, yellow; 2 wing-bars; abdomen and under tail-coverts, white ; large white tail-spots ; $q$. duller; yellow often obscure.

Breeds throughout (in $\mathrm{Pa}$. in $\mathrm{mts}$, , and in $\mathrm{S} . \mathrm{N} . \mathrm{J}$.) ; nest, generally in pines or cedars, delicate; eggs, in May, 4, white, spotted; first warbler to arrive in spring; runs along branches.

\section{PROTHONOTARY WARBLER.}

Yellow, ashy-blue-Yellow.

$5^{\mathrm{T} / 2}$. Bill, large and black; golden-yellow head, fading to olivaceous back; ashy-blue rump, wings, and tail ; tail- 
feathers largely white-spotted; below, yellow, paler on abdomen; in fullest plumage, head sometimes orange.

A southern species, extremely rare; no record in N. J. ; nest, in holes; prefers damp places.

\section{ซร. SUMMER YELLOW-BIRD.}

Golden-yellow, faintly streaked.

5. Breast, and sometimes back, streaked with orangebrown, often obscurely; no white on tail.

Nest, of fine grass and cottony material, lined with wool, hair, feathers, generally in low bush; eggs, about June Ist, 4-5, grayish-white, variously spotted with divers tints.

\section{NASHVILLE WARBLER.}

Olive-green-Yellow.

41/2-5. Head and neck, ashy; inconspicuous chestnut spot on crown ; white eye-ring; paler on abdomen; $q$ has crown-spot and ash on head less noticeable.

Breeds from S. E. N. Y. northward, but occasionally in mts. of Pa. ; nest, on ground; eggs, about June Ist, white, variously marked.

\section{BLUE YELLOW-BACKED WARBLER: PARULA WARBLER.}

\section{Ashy-blue_Yellow.}

$4 \frac{1}{2}$. Yellow spot on middle of back; white wing-bars; tail, white-spotted; throat and upper breast, yellow; collar of rich brown across breast; other under parts, white. , less bright, more indistinctly marked.

Chiefly on northern edge, but locally abundant in N J.; nest, largely of mosses, globular; eggs, early in June, 4-5, white, spotted with reddish-brown and lilac; a delicate species. 
* Nos 78-86: Without bright yellow on ВОтH throat and breast (or on neither).

\section{GREAT CRESTED FLYCATCHER.}

Greenish-olive-Dark ash, yellow.

$81 / 2-9$. Crown-feathers, erectile; tail, largely chestnut; throat and upper breast, dark ash, passing abruptly into yellow.

Throughout, but not abundant; nest, in hole of tree, usually contains snake-skins ; eggs, early in June, $4-5$, creamy or buff, curiously dark-streaked and spotted.

\section{SEA-SIDE FINCH.}

Olive-brown, streaked - Brownish-white, streaked.

6. Lore, bright yellow; edge of wing, yellow; faintly streaked below.

North to Mass., in salt marshes of coast ; not found in $\mathrm{Pa}$. ; nest, in tussock of grass, near water; eggs, grayish-white, finely and evenly spotted ; abundant.

\section{9a: ACADIAN FLYCATCHER.}

Olive-green-Whitish.

$53 / 4-61 / 4$. See 24.

\section{YELLOW.BELLIED FLYCATCHER.}

\section{Olive-green-Olivaceous-yellow.}

$5 \% 2$. Eye-ring and wing-bars, yellow; breast and sides, olivaceous-yellow ; abdomen, bright yellow.

Authorities differ as to habitat of this species, the records of its nesting mostly coming from Mie. and Pa. (particularly in mts.), also rarely in Ad'r'ks; nest, in damp places, near ground; eggs, 4-5, white, spotted; note, pe-a, uttered slowly.

\section{SAVANNA SPARROW.}

Brownish-gray, dark-streaked-Whitish, dark-streaked. $5 \%$. Faint median crown-line; often a cast of yellow about 
head; superciliary line and edge of wing, yellowish; no white in tail; breast and sides, thickly dark-streaked.

Breeds chiefly in N. E., only migrant in Pa. ; winters in S. Pa. and S. N. J.; nest, rude, on ground; eggs, early in May, 4-6, motley colored; prefers salt marshes; runs rapidly on ground.

\section{SHARP-TAILED SPARROW.}

Olive-brown, streaked-Brownish-white, streaked.

$5 \frac{1}{2}$. Superciliary rich buff line; see 7 .

\section{WHITE-EYED VIREO.}

Bright olive-green —White.

5. Eye, white; eye-ring, 2 wing-bars, sides of breast, and under tail-coverts, yellow.

Nest, in low tree or bush, very near ground, often of newspaper, or strips of hornet's or wasp's nest; eggs, June Ist, 4-5, like those of red-eyed vireo; a dashing singer.

\section{SOLITARY VIREO.}

Olive-green-White.

51/2. See 27.

\section{HENSLOW'S SPARROW.}

Buff-brown, dark-streaked-Buff-white, streaked.

5. Edge of wing, yellow; see $\mathbf{1 0 5}$.

\section{YELLOW-WINGED SPARROW.}

Brown, black-streaked_-Buff, not streaked.

5. See $\mathbf{1 0 6 .}$ 


\section{BLACK AND YELLOW LIST.}

Nos. 87-106: Showing both Black and Yellow.

* Nos. 87-92: Black and yellow on breast.

\section{MEADOW LARK.}

Brown, black-streaked-Black and yellow.

101/2. Outer tail-feathers, largely white; below, bright yellow, with large black crescent on breast.

Breeds throughout ; in winter exceptionally in S. N. E., more abundant southward; permanent in N. J. ; nest, on ground, chiefly in meadows; eggs, latter part of May, 4-5, white, spotted with brown and lilac; flies straight, with rapid wing-beat.

\section{BALTIMORE ORIOLE: GOLDEN ROBIN.}

\section{Black and orange.}

7 $1 / 2-8$. Entire head, neck, and back, black; rump and upper tail-coverts, orange; wings, black, white-spotted; tail, black and orange ; below, except black throat and upper breast, orange ; orange throughout of variable intensity ; \& , smaller, duller, black more or less replaced by olive ; below, pale orange throughout, mixed with white, and only suggestion of black on throat.

Nest, deep and pensile, finely woven; eggs, June Ist, 4-6, white, slightly tinged and marked; fine singer, artistic builder.

\section{8a. LINCOLN'S SPARROW.}

Grayish-brown, streaked-Whitish, streaked. 


\section{CANADIAN FLYCATCHING WARBLER.}

\section{Ashy-blue-Yellow, black-streaked.}

5-5 $\frac{1}{2}$. Crown, black-streaked; superciliary line and whole under side, except white under tail-coverts, yellow ; chain of black down each side of throat, connecting with necklace of jet across breast ; wings and tail, unmarked; o has black markings obscure.

Breeds throughout $\mathrm{N}$. E. and occasionally in mts. of $\mathrm{Pa}$. ; only migrant in N. J. ; nest, often loosely built of pine-needles, on ground, in swampy woodland; eggs, 4-5, white, "clouded delicately at larger end with brown and lilac; " a finer singer than most warblers.

\section{HOODED WARBLER. \\ Yellowish-olive-Yellow and black.}

$5 \frac{1}{4}$. Forehead and sides of face, rich yellow, surrounded by black hood covering rest of head, neck, and throat; large white spots on tail ; hood not perfect till $3 \mathrm{~d} \mathrm{yr.;} \mathrm{f}$ generally shows only ragged traces of it.

Rarely north of Conn. ; nest, low in bush; eggs, 4, white, redspotted ; frequently spreads tail ; a beautiful species.

\section{REDSTART.}

Glossy-black, flame-spotted (or yellow).

$5 \frac{1}{4}$. See 63.

\section{PRAIRIE WARBLER. \\ Olive-Yellow, black-streaked.}

$4 \frac{1}{2}$. Forehead and superciliary line, yellow; a V-shaped black mark on side of face ; brick-red spots on back; 2 yellow wing-bars; tail, white-spotted; side-streaks on throat and breast, black.

Seldom north of Mass. ; abundant in S. N. J. : rarely breeds in Pa. ; nest, of grass and woody fibre, lined with horse-hair, feathers, etc., within a few feet of the ground; eggs, June rst, $3-5$, white, marked with different shades; a flycatcher, like the redstart. 
* * Nos. 93-97 : Breast pure jellow (or (97) black-bordired).

\section{YELLOW-BREASTED CHAT. \\ Bright olive-green—Rich yellow.}

7. Superciliary line and abdomen, white; lore, black.

Rarely as far north as Mass. ; nest, in bush, near ground ; eggs, 3-4. clear white ground, variable in markings; eccentric singer and acrobat.

\section{KENTUCKY WARBLER. Olive-green-Bright yellow.}

$5 \% 4$. Black crown; rich yellow superciliary line curling around eye ; black line below eye and running down side of neck; no markings on wings and tail ; sides, olive-shaded.

Rarely north to S. E. N. Y., rather common in $\mathrm{Pa}$., very rare in N. J. ; nest, on ground; eggs, 4-5, lustrous white, dotted with reddish; more terrestrial than most warblers; walks, like oven-bird.

\section{BLUE-WINGED YELLOW WARBLER.}

Yellow-olive, ashy-blue-Yellow.

5. Bill, dark; black cye-stripe; golden-yellow head, fading to olivaceous back and rump; ashy-blue wings and tail ; 2 whitish wing-bars; large white spots on tail ; distinguished from "prothonotary" by black eye-stripe, white wing-bars, and olivaceous rump.

North to southern N. E. ; nest, in tuft of grass, a circlet of oakleaves and thin bark, finely and deeply lined with fine grass and horsehair ; eggs, latter part of MIay, 4-6, white, spotted at larger end.

\section{D6. MARYLAND YELLOW THROAT.}

\section{Olive-green —Yellow.}

5. Forehead and wide band through eye, black, grayedged above ; abdomen, white ; $q$, no black, nor gray edge ; yellow restricted.

Nest, of leaves, grass, hair, on ground, in damp spot; eggs, latter part of May, 4-6, pure white or creamy, variously marked; abundant. 


\section{BLACKBURNIAN WARBLER.}

\section{Black, white-marked-Orange, whitish.}

$4 \frac{1}{2}$. Head, throat, and breast, flame-color, interspersed or bordered with abrupt clear black markings ; large wingspots and much of tail, white; sides, black-streaked; abdomen, whitish or yellowish; $q$ has black replaced by olive, black-streaked, and orange replaced by yellow, and white of wings restricted.

Breeds in northerly part of range and in mts. of $\mathrm{Pa}$. ; nest, of strips of bark, silky fibre, feathers, etc., higher from ground than most warblers; eggs, middle of June, 4-5, white, marked; a splendid species.

* * Nos. 98-106 : With no yellow on breast.

\section{YELLOW-BILLED CUCKOO.}

Brownish-gray —White.

I I-I2. Lower mandible and part of upper, yellow ; central tail-feathers, like back, the rest black, broadly whitetipped.

Nest, very crude and loose ; eggs, about June Ist, 4-8, lighter green than in the "black-billed."

\section{BLACK-THROATED BUNTING.}

\section{Grayish-brown-Black, whitish.}

$6 \% / 2$. Crown, olive-yellow; yellow superciliary line; back, black-streaked ; edge of wing, yellow ; wing-bars, chestnut ; chin, white; large black area on throat; breast and abdomen, yellowish-white; sides, grayish-white.

Northward, to Mass., rarely ; nest, on ground or near it ; eggs, latter part of May, 4-5, greenish-white, seldom spotted. 


\section{OVEN-BIRD : GOLDEN-CROWNED THRUSH,}

Rich olive-White, dark-spotted.

51/2-61/2. Crown, buff-orange, black-bordered; see 41.

\section{CHESTNUT-SIDED WARBLER.}

Streaked with black and pale yellow-White.

$51 / 2$. Forchead and crown, yellow, bordered with white, the white bordered with black; large black mark on side of face ; white wing-bars ; tail, white-spotted ; large chestnut stripe down side of breast; $q$, less strongly marked.

Throughout; in Pa. and N. J. it breeds chiefly in mts. ; nest, of narrow strips of thin bark, dried grass, hair, in low bush in rather open land; eggs, June Ist, 4-5, white, spotted.

\section{1 a. SHARP-TAILED SPARROW.}

Olive-brown, streaked-Brownish-white, streaked.

\section{$5 \% \frac{1}{2}$. See 7 .}

\section{BLACK-THROATED GREEN WARBLER.}

Yellow, olive-green-Black, white.

5. Forehead and entire side of fice, rich yellow; wings and tail, dark; 2 white wing-bars; outer tail-feathers, largely white ; throat and breast, jet black ; otherwise, below, white or whitish; $q$ (and $\hat{o}$ in fall) has little or no black.

Especially abundant in N. E.; breeds in higher mts. of $\mathrm{Pa}$; only migrant in N. J. ; nest, small and pretty, "usually in pines," ro-50 feet from ground; eggs, in June, 3-4, creamy, marked; beautiful, and with continuous simple song through sunmer. 


\section{WHITE-THROATED WARBLER.}

Slaty-blue-White.

5. Superciliary line and cheeks, white ; narrow black eyestripe; crown and large wing-patch, rich yellow; below, entirely white.

Extremely rare; mostly found in N. E. ; nest and eggs, as yet undiscovered.

\section{BLUE GOLDEN-WINGED WARBLER.}

\section{Slaty-blue-Black, white.}

5. Bill and broad eye-stripe, black; crown and large wing-patch, rich yellow ; tail, white-spotted ; throat, black; otherwise, below, white or yellow-tinged; i has less distinct markings.

Northward to S. N. E.; in Pa. rare migrant, possibly breeding ; very rare in N. J.; nest, on ground; eggs, June Ist, 4-5, white, with reddish-brown dots.

\section{HENSLOW'S SPARROW.}

Buff-brown, black-streaked-Buff-white, streaked.

5. Crown, blackish, with buff median line ; edge of wing, yellow; throat and abdomen, whitish; breast and sides, strongly dark-streaked; chiefly distinguished from "yellow-winged " by streaks below.

Not common so far north as $\mathrm{N}$. E. ; only rare migrant in $\mathrm{Pa}$. ; rarer than "yellow-winged" sparrow; nest, in tuft of grass; eggs, 4-5, g:eenish-white, sprinkled with red; in open grass-land.

\section{YELLOW-WINGED SPARROW.}

Brown, black-streaked-Buff.

5. Crown, blackish, with buff median line ; short superciliary line, yellowish; edge of zving, yellow; spot on wing, 
yellowish ; below, rich buff, unstreaked; abdomen, whitish.

Nest, on ground, in open land; eggs, June Ist, 4-5, pure white, spotted; frequents open sandy fields.

\section{BLUE OR RED LIST.}

Nos. 107-118: Showing neither Black nor Yellow.

\section{BELTED KINGFISHER.}

Ashy-blue-Blue, white.

I2 $1 / 2$. Long, thin crest, a little darker; wings and tail, dark, white-spotted; below, white on throat and extending around neck, but not meeting on hind-neck; broad breast-band and sides, ashy-blue; abdomen, white; $q$ has abdomen-band and sides chestnut.

Nest, a deep horizontal hole in sand-bank, enlarged at inner end, lined with a few fish-bones; eggs, June Ist, 6-8, pure white; always near water; has peculiar rattling notes.

\section{7a. PURPLE MARTIN.}

\section{See 33.}

\section{Lustrous steel-blue.}

\section{BLUEBIRD.}

Lustrous-blue_Chestnut, white.

$61 / 2-7$. Throat, breast, and sides, chestnut; abdomen, white.

Nest, of various fine materials, in natural or artificial hole in tree, post, etc. ; eggs, May Ist, 4-6, light blue ; earliest herald of spring; permanent in N. J.

\section{BARN SWALLOW.}

\section{Steel-blue-Chestnut.}

6-7. Forehead, chestnut ; tail, deeply forked, white-spotted ; below, various shades of chestnut, deepest on breast; 
an imperfect steel-blue collar across breast; distinguished from all other swallows by forked tail.

Nest, of mud, lined with soft material; eggs, middle of May, $3^{-6}$, white, thickly spotted.

\section{SOLITARY VIREO: BLUE-HEADED VIREO. Olive-green-White.}

5\%2. Head, bluish-ash; see $\mathbf{2 7}$.

\section{INDIGO-BIRD.}

Indigo-blue.

$5^{1 / 2}$. Wings and tail, blackish; see 39.

\section{CLIFF SWALLOW: EAVE SWALLOW.}

\section{Steel-blue Chestnut.}

5-5 $1 / 2$. Forehead, light brown; sides of head and rump, chestnut; wings and tail, dark; tail, emarginate; throat and breast, chestnut, breast paler, with steel-blue spot; abdomen, white.

Nest, somewhat gourd-shaped, of mud, lined, under eaves, in colonies; eggs, middle of May, 3-6, white, thickly spotted.

\section{CCERULEAN WARBLER.}

Azure-blue, dark-streaked —White, blue-streaked.

$4 \frac{1}{2}$. See 55.

\section{SUMMER RED-BIRD: SUMMER TANAGER.}

\section{Vermilion.}

7 1/2-8. + , above, brownish-olive; below, pale buff-yellow.

Rarely north to Mass., seldom in Conn., rare in $\mathrm{Pa}$., not found in N. J. ; nest, rude, in tree or thicket, not far from ground; eggs, latter part of May, 3-5, pale greenish-blue, thickly spotted.

\section{1 ia. CARDINAL GROSBEAK.}

\section{Vermilion.}

$81 / 2$. Crested; see 58. 


\section{PURPLE FINCH.}

Carmine, brownish.

6. Large bill ; crown-feathers, erectile ; throughout, carmine of varied intensity, fore-part brightest; back, darkstreaked ; wings and tail, darker; abdomen, white ; $q$, olivebrown, dark-streaked; abdomen, white.

Breeds throughout, but sparingly in $\mathrm{Pa}$. and N. J.; in winter, rarely north to Mass., occasionally in Ad'r'ks, but rather abundant in $\mathrm{Pa}$. ; nest, of various vegetable fibres, in tree, not far from ground; eggs, latter part of May, 4-5, pale green, thinly dark-spotted; a fine warbler.

\section{VESPER SPARROW.}

Grayish-brown, dark-streaked-White, streaked.

6. Wing-patch, chestnut; see $\mathbf{6}$.

\section{FIELD SPARROW.}

Light brown, dark-streaked-Brownish-white.

$5 \%$. Crown, reddish; see 70.

\section{RUBY-THROATED HUMMING-BIRD.}

Golden-green—Ruby, white.

31/4. Wings and tail, brownish-purple; tail, forked or emarginate; throat, metallic ruby-red ; sides, green ; breast and abdomen, white; + , smaller ; tail, black-barred ; outer feathers, white-tipped; throat, white.

Nest, delicate and elegant; eggs, early June, 2, white; America (North and South) alone of all the continents possesses hummingbirds.

Winter Birds Found Regularly or Occasionally in Summer.

(The bird's proper number precedes, its length follows, its name.)

184. Brown Creeper; 5 $1 / 2$; Mass. and northward, and in mts. of $\mathrm{Pa}$., regularly. 
201. SHORE LARK; 7-71/2; Ad'r'ks, not uncommon.

186. Winter Wren; 4 ; on northern edge, and in mts. of Pa., regularly.

185. PINE FINCH; 43/4; on northern edge (exceptionally in Mass.), and in mts. of $\mathrm{Pa}$., regularly.

191. SNOW-BIRD; $6-6 \frac{1}{2}$; on northern edge, and in mts. of $\mathrm{Pa}$, regularly; said to breed on Mt. Wachusett, Mass.

199. Canada Nuthatch ; $4 \frac{1}{2}-5$; Ad'r'ks, and in mts. of Pa., regularly.

196. Common Crossbill; 6 ; on northern edge, and in mts. of $\mathrm{Pa}$, regularly.

197. White-Winged Crossbili, 6 ; on northern edge, and in mts. of $\mathrm{Pa}$, regularly ; rare.

187. ButCHER-BIRD; 9-IO; on northern edge, regularly.

195. Pine Grosbeak ; 8-9; on northern edge, regularly.

193. Hudsonian ChickadeE; 5 ; on northern edge, regularly.

202. Golden-CROWNED Kinglet ; $4-4 \frac{1}{2}$; on northern edge, regularly.

\section{Migrant Birds Found Regularly or Occasionally in Summer in $\mathbf{P a}$.}

169. MOURniNG WARbLer; 5-5 $1 / 2$; in mts., regularly.

161. Black-throated Blue Warbler; 5 ; in mts., regularly.

150. Olive-Backed Thrush ; $7-7 \frac{1}{2}$; in mts., occasionally.

151. Hermit Thrush; $7-71 / 2$; in mts., occasionally.

171. BLACK-AND-YELLOW WARBLER ; 5 ; in mts., occasionally.

175. Yellow-RUMPED WARBLer; $5 \frac{1}{2} 2$; in mts., occasion. ally.

156. Bronzed Grackle; I2-I3 ; IV. Pa., regularly.

162. Wild Pigeon; 16 ; occasionally.

178. AMERICAN SNIPE; IO; occasionally. 


\section{SUMMER GROUP.}

\section{WATER BIRDS.}

In sub-groups, according to general habitat.

\section{UPLAND PLOVER.}

Blackish_—Pale rufous, black-streaked.

12. Bill, yellow; above, blackish, speckled with white or tawny; tail, orange-brown, dark-barred, white-tipped; upper breast and sides, black-streaked.

In uplands and meadows; a " game-bird ;" nest, of straw or grass, on ground; eggs, 4, clay-colored or creamy, spotted.

\section{WOODCOCK.}

Variegation of dark tints - Variable pale brown.

Io. Bill, very long; large head; "large eyes in back upper corner;" dark stripe from bill to eye; tail, very short, barred ; \&, larger.

Throughout, occasionally in winter; a winter bird in N. J. ; nest, on ground; eggs, in April, 4, thickly marked; prefers damp places.

\section{RAILS.}

This family, two species of which are called marsh hens, somewhat resemble in appearance the domestic fowl. They are to be found almost exclusively in open marshes, nesting on the ground, and secreting themselves in the thick growth of reeds and grasses.

\section{KING RAIL: FRESH-WATER MARSH HEN.}

Brownish-black, lighter streaked-Cinnamon-red.

I7-I9. Bill, long; dark eye-stripe; streaked on upper 
side ; tail, short ; below, breast rich cinnamon-red, throat and abdomen paler ; flanks, blackish, white-barred.

Locally in Pa. and N. J. in fresh-water marshes; casually to Conn. : nest and eggs, as in clapper rail.

\section{CLAPPER RAIL: SALT-WATER MARSH HEN : MUD HEN.}

\section{Brownish-gray, variegated-Dull brown.}

I4-I6. Bill, long; superciliary line and throat, whitish; almost no tail ; sides and under tail-coverts, white-barred.

Abundant along southern coast of $\mathrm{N}$. J., accidentally in Pa., straggling to Mass. ; in salt marshes; nest, of reeds and grasses, on wet ground; eggs, 6-I2, whitish to buff, spotted.

\section{VIRGINIA RAIL.}

\section{Olive-brown-Cinnamon-red.}

8-10. A small fac-simile of king rail (21).

Breeds throughout, in fresh or salt marshes; nest and eggs, as in king rail, but smaller.

\section{CAROLINA RAIL: COMMON RAIL.}

Dark olive-brown, white-specked-Dark gray.

8-9. Bill, short; fore part of face and central line of throat, black; tail, short ; flanks, black-and-white barred.

Breeds throughout, but in N. J. chiefly migrant; especially abundant in Aug. and Sept.; nest, as in other rails ; eggs, 6-12, drab, spotted; abundant game bird.

\section{YELLOW RAIL.}

Brownish-yellow, black-streaked-Paler.

6. Lighter superciliary line; thickly spotted above with white; flanks, black-and-white barred.

Nest, and habits, as in other rails; eggs, 6, buff-brown, spotted ; in $\mathrm{Pa}$. and $\mathrm{N}$. J. a rare migrant. 


\section{FLORIDA GALLINULE: RED-BILLED MUD HEN. Blackish.}

12-14. Bill and horny plate, from base of bill upward, brightred; bill, tipped with yellow; back, brownish-olive ; flanks, white-barred; rear, white.

Breeds rarely as far north as Mass., rather rare migrant in $\mathrm{Pa}$. and N. J. ; nest, a hollow in a mass of dried reeds, almost floating in water; eggs, IO-I4.

\section{AMERICAN COOT: WHITE-BILLED MUD HEN.}

\section{Dark slate-Lighter.}

14-16. Bill, whitish; head, neck, and tail, blackish ; below, grayish; under tail-coverts, white.

Breeds rarely in $\mathrm{N}$. E., only migrant in $\mathrm{Pa}$. and $\mathrm{N}$. J. ; frequents reedy marshes and stagnant water ; nest, sometimes on dry ground, oftener built in water, like grebe's, almost floating ; eggs, I2, clay-color, minutely brown-dotted.

\section{SEMIPALMATED TATTLER: WILLET.}

Ashy, black-speckled-White, spotted.

16. Bill, long; pure white area on wings; breast, often tinged with brown; entire under side, spotted or streaked; blue legs.

Breeds in salt or fresh marshes; in $\mathrm{Pa}$. only rare migrant; locally abundant, but most numerous in migration ; nest, in tussock of grass ; eggs, 3-4, various ground-tints, strongly spotted; noisy when alarmed.

\section{AMERICAN BITTERN.}

Variegation of brown, black, tawny, etc._Light tawny, spotted.

23-34. Eye, yellow; a glossy black patch on each side of neck; tail, short ; legs, greenish-yellow.

Breeds throughout, in bogs; commonly found solitary ; nest, on ground; eggs, 3-5, brownish-drab. 


\section{LEAST BITTERN. \\ Greenish-black-Brownish-yellow.}

I I-I4. Fye, yellow; crown, back, and tail, glossy greenish-black ; hind-neck, chestnut ; sides of neck, breast, and abdomen, brownish-yellow ; throat, whitish ; blackish patch on side of breast; legs, green ; $q$ has chestnut crown and back.

Breeds throughout, but rare north of Mass. and not abundant south; in marshes; nest, on or near ground; eggs, $3-5$, white, bluetinged.

\section{HERONS.}

These are the largest of our water birds, living in wooded swamps, often in colonies, and nesting in trees.

\section{GREAT BLUE HERON.}

\section{Slaty-blue-Black.}

42-50. Bill and eyes, yellow; crest of long feathers and 2 plumes, black; head, black and white; long, slender shoulder-feathers, grayish; long legs.

Nest, in tree or bush; eggs, 3-4, pale greenish-blue; found in pairs, small flocks, more rarely in large heronries; identified by great size and dark plumage; winters occasionally in N. J.

\section{GREAT WHITE HERON.}

\section{Pure white.}

36-42. No crest, but in breeding season with splendid train of long plumes from back, reaching beyond tail ; legs, black.

A southern species, but very rarely throughout range; nesting, like "great blue." 


\section{SMALL WHITE HERON: EGRET.}

Pure white.

24. Bill, black; eyes, yellow; crest of long feathers, a train of plumes from back, and lengthened feathers on lower neck in breeding season; legs, black ; eggs, 4 .

Extremely rare.

\section{LITTLE BLUE HERON.}

Dark grayish-blue.

24. Eyes, yellow; head and neck, maroon ; this species is sometimes pure white, then almost precisely like "small white heron."

A southern species, very rare in Northern States; nesting, as in egret.

\section{NIGHT HERON: QUA-BIRD: SQUAWK.} Bluish-gray, dark green-Whitish.

24. Long black bill ; eye, red ; forehead, white ; crown, shoulders, and interscapulars, glossy dark green; 2 or 3 very long slender white plumes from hind head; otherwise, above, bluish-gray ; legs, yellow.

Most abundant heron; usually gregarious; occasionally in winter ; nest, high in tree; eggs, early in June, $4-6$, pale green.

\section{GREEN HERON.}

\section{Dark green—Dark brown.}

16-18. Bill, long and blackish; crown and long plumes of hind-head, glossy green, sometimes iridescent; back, slightly bluish; neck, purplish chestnut; white line down middle of throat and breast ; legs, greenish-yellow.

In pairs, rather than gregarious; nest, in tree or bush; eggs, in May, 5-6, pale greenish-blue. 
The two following are found along ponds and streams:

\section{3\%. SUMMER DUCK.}

Blackish, iridescent-Chestnut, white, buff.

I9. Slightly crested; head, with green and purple lustre, and white-streaked; shoulders, black ; throat and breast, chestnut; white crescent on each side in front of wing; sides, buff, black-lined; abdomen, white; $\&$, duller and less distinctly marked.

Breeds throughout in woody places near water; nest, in tree-hole ; eggs, about I2, pale drab ; handsomest of the ducks.

\section{PIED-BILLED GREBE : DABCHICK : HELL DIVER.}

Brownish-black-Ashy, dark-spotted.

13. Crown and hind-neck, grayish-black; large black throat-patch; below, somewhat spotted; abdomen, white.

Breeds rarely throughout ; in winter, frequent in Pa., rare in $\mathrm{N}$. J.; nest, a compact mass of aquatic plants, on edge of pond, or built up from beneath water; a sort of floating island; eggs, $5-6$, whitish, unspotted; more abundant in migration.

\section{PLOVERS.}

The two allied families, plovers and sandpipers, are mostly small wading coast-birds, nearly all of them breeding far to the north ; only four species can be said to summer within territory.

\section{SEMIPALMATED PLOVER.}

Ashy-brown-White.

7. Black band across forehead and over eye, and one across breast ; legs, yellowish.

Breeds only very rarely in territory, but an abundant migrant in May, Aug., and Sept. on coast, and, in Pa., at Lake Erie, and along largest rivers. 


\section{PIPING PLOVER.}

\section{Pale ashy-brown-White.}

$6 \frac{1}{2}$. Black line across forchead; sides of face, white; black band across upper breast, often interrupted, and not circling neck ; $q$ has black of forehead and neck obscure.

Breeds anywhere along coast, but most abundant in migration, when it is found in flocks; nest, in tussock of grass ; eggs, June Ist, 4 , clay-colored or creamy, with a few small dots.

\section{KILDEER PLOVER.}

\section{Grayish-brown-White, black-banded.}

9-10. Black line each side of crown, meeting on forehead; white superciliary line; black eye-stripe ; tail, with I to 3 black bars, white-tipped; below, white, with 2 broad black bands across upper breast, reaching to hind-neck.

This and spotted sandpiper the most abundant of the "waders" breeding in territory ; not gregarious; an inland rather than a coastbird; name from sound of note ; nest, in grass, near water; eggs, in May, 4, creamy to clay-color, spotted; winters in S. Pa.

\section{SPOTTED SANDPIPER.}

\section{Ashy-olive, black-speckled-White, spotted.}

$7 \frac{1}{2}$. White superciliary line; white on wings; tail, whitebarred; below, pure white, with large black spots; feet, pinkish.

Along every fresh-water course and on N. J. coast ; peculiar teetering of body, and low flight; nest, on ground, near water; eggs, 4 . tinted and marked.

\section{GULLS AND TERNS.}

These are beautiful aërial coast-birds, the former, for the most part, coming from the north in winter, the latter from the south in summer; they breed only locally within territory. 


\section{LAUGHING GULL: BLACK-HEADED GULL.}

\section{Black, slate, white-White.}

I6-19. Head and fore-neck all round, blackish; rest of neck, rump, tail, and below, white; wings and back, slate.

A southern species, seen only in summer; breeds along coast; nest, on ground, commonly on sand, of sea-weeds, etc.; eggs, 3 , greenish, spotted; in Pa., only migrant on Susquehanna River.

\section{ARCTIC TERN.}

\section{Pearly-blue.}

I4-17. Bill, red; entire top of head, black; tail, white ; below, a little lighter blue than above; under tail-coverts, pure white.

Breeds in same localities as "common tern;" nesting and eggs, similar.

\section{COMMON TERN: SEA SWALLOW.}

\section{Pearly-blue —White.}

I3-16. Bill, red; entire top of head, black; back and wings, pearly-blue; tail, white, forked; feet, red.

Breeds on several islands off coast of N. E., and a few on N. J. coast; nest, on ground, of dried grass, or simply a slight depression; eggs, middle of June, 3 , drab to buff, splashed with dark spots; very gregarious.

\section{ROSEATE TERN.}

Pale pearly-blue — White, rose-tinted.

12-I6. Bill, black; glossy black cap; tail, white, forked; feet, red.

Breeds in same localities as "common tern;" nest and eggs, similar. 


\section{4\%. LEAST TERN. \\ Pearly-blue White.}

9. Bill, yellow, black-tipped; glossy black cap; tail, forked; feet, pale orange.

Breeds in same localities as foregoing; eggs, I-3, laid on bare sand or in slight depression.

\section{STORMY PETREL: "MOTHER CAREY'S CHICKENS."}

\section{Blackish.}

8. Bill, black; rump, white; tail, forked.

Breeds along N. E. coast ; rather common ; nest, in horizontal excavation in ground; egg, single, white; strictly maritime, coming to land only to breed.

There are three species of stormy petrels to be found, but almost or quite indistinguishable at field-range ; the most abundant, Leach's, has forked tail, the other two, square tails.

\section{MIGRANT GROUP.}

\section{LAND BIRDS.}

Comprising those species that arrive from the south in spring, linger a short time, go north to breed-in the northern part of the States of Me., N. H., and Vt., and the Adirondack region of $N$. $Y$., or beyond-return in the same manner in the fall, and winter beyond the southern boundary; the periods for this group within territory are approximately April I-June I and Sept. I-Nov. I. 


\section{NEUTRAL LIST.}

Nos. 149-155: Showing neither Black, Yellow, Blue, nor Red.

(All but the last three have breast dark-spotted.)

\section{GRAY-CHEEKED THRUSH: ARCTIC OR ALICE'S THRUSH.}

Brownish-olive-White, dark-spotted.

$7 \frac{1}{2}-8$. Below, no buff tinge; breast, dark-spotted.

Doubtful if it breeds even on northern edge; nest, clumsy, on ground; eggs, early June, 3-4, light greenish-blue, thickly spotted; song said to be different from that of all other thrushes; possibly a variety of the "olive-backed."

\section{OLIVE-BACKED THRUSH.}

Brownish-olive_-Whitish, dark-spotted.

7-7 $1 / 2$. Buff eye-ring; above, dull olive; below, whitish; breast, buff-tinged and thickly spotted.

Breeds on northern edge and occasionally in higher $\mathrm{mts}$. of $\mathrm{Pa}$. ; nest, bulky, without mud, within few feet of ground; eggs, early June, 3-4, light greenish, variously spotted; ordinary singer.

\section{HERMIT THRUSH.}

Soft brownish-olive-Buff-white, spotted.

7-7 1/2. Yellowish eye-ring; above, dusky olive, becoming tawny on rump and tail; below, white ; breast, buff-tinged and strongly spotted.

Breeds on northern edge and occasionally in higher mts. of Pa.; nest, rather coarse and large, without mud, generally on ground; eggs, early June, $3-4$, light greenish-blue; winters in $\mathrm{S} . \mathrm{Pa}$. and N. J.; the gem of thrushes. 


\section{FOX SPARROW.}

\section{Reddish-tawny-White, spotted.}

7. Back, ashy-streaked; 2 narrow white wing-bars; below, prominent rusty-red streaks, except on abdomen..

Does not breed on northern edge; nest, on or near ground; eggs, bluish-white, heavily spotted with rusty-brown; winters in S. N. J.; a large and handsome sparrow, the most welcome of any save song sparrow, and finest singer; comes with March winds.

\section{ORANGE-CROWNED WARBLER.}

Olive-green-Greenish-white, streaky.

$4 \frac{1}{2}-5$. Obscure crown-spot of orange-brown (often absent) ; eye-ring and superciliary line, yellowish ; sides, olive-shaded.

Breeds in Arctic regions; nest and eggs, unknown; very rare; almost no record in N. J.

\section{TENNESSEE WARBLER.}

Yellowish-olive_-Whitish.

43/4. Superciliary line, white; above, fore-part ashy.

Practically migrant, though breeding rarely down to Mass.; locally common in Ad'r'ks; nest, of grasses, mosses, etc., lined with hair ; eggs, pearly-white, marked.

\section{RUBY-CROWNED KINGLET.}

Greenish-olive - Whitish or yellow-tinged.

4-41/2. See 17\%. Many specimens (i.e., immature and probably $q$ ) lack the ruby crown. 


\section{BLACK LIST.}

I Nos. 156-161 : Showing black, but no yellow NOR RED.

\section{BRONZED CROW BLACKBIRD: BRONZED GRACKLE.}

\section{Iridescent black.}

12-13. Threefold iridescence in rather distinct areas; head, neck, and breast, stcel-blue; wings and tail, violit and purple, otherwise shining brassy.

Breeds on northern edge, and commonly in western part of Pa.; nest and habits, as in purple grackle.

\section{5\%. RUSTY GRACKLE.}

\section{Rusty black.}

9. Summer dress, iridescent black, which, in migration, is overspread with " rusty ;" bill, black; eye, pale white, or yellowish ; $q$, above, rusty-brown ; below, same, mixed with grayish-black; pale superciliary line.

Breeds on northern edge; winters rarely in $\mathrm{S} . \mathrm{N}$. J. and locally in $\mathrm{S}$. Conn. ; nest, large, of grass and mud, lined; eggs, 4 , greenish, variable, brown-spotted.

\section{WHITE-CROWNED SPARROW.}

Dark ash, brown-streaked-Light ash.

7. Forehead, black; broad white median and superciliary lines meeting on hind-head, median line bordered by black; black eye-stripe ; rump, brownish ; 2 white wingbars; chin and abdomen, whitish; flanks and under tailcoverts, brownish; no yellow.

Breeds on northern edge; nest, on ground or in bush; eggs, 4-5, very variable in color; observe difference from " white-throated spar. row ;" found exceptionally in winter. 


\title{
159. WHITE-THROATED SPARROW.
}

\begin{abstract}
Reddish-brown, black-streaked-White, ashy.
\end{abstract}
7. See 173. Short yellow stripe may escape notice.

\section{BLACK-POLL WARBLER.}

Olive, black-streaked-White.

51/2. Whole top of head, glossy black; sides of head, white; wing-bars and tail-spots, white ; sides of throat and breast, black-streaked ; क , minus black crown, and, below, white less pure, streaks less marked.

Breeds exceptionally on northern edge; nest, large for bird, oftener in evergreens, a few feet from ground; eggs, late in June, 5, variously tinted; generally the last spring migrant, about June Ist.

\section{BLACK-THROATED BLUE WARBLER.}

Slaty-blue-Black, white.

5. Sides of head, throat, and sides of body, jet black; wings and tail, dark, former with large white spot on the cdge; below, except throat and sides, clear white ; $\&$, dull olive above ; wing-spot, somewhat obscure ; below, whitish.

Breeds on northern edge, rarely a little south, and in the mts. of Pa. ; nest, of various fine materials ; eggs, June Ist, $3-5$, " creamywhite, tinged, when fresh, with rose-color," and spotted; a beauty.

If T Nos. 162-164: Showing black AND RED, but no yellow.

\section{WILD PIGEON: PASSENGER PIGEON.}

Grayish-blue —Purplish-red.

16. Bill, black; eye, red; metallic gleam on neck; shoulders, black-spotted; ends of wings and middle tailfeathers, black; outer tail-feathers, whitish, black, and chestnut; tail, long and graduated; throat and breast, 
purplish-red, abdomen lighter; sides, grayish-blue ; feet, red; $q$ has red of breast replaced by grayish-brown.

Mostly migrant, breeding a little in northern N. E. and $\mathrm{Pa}$. ; nest, frail, in tree ; eggs, in April or May, I-2, pure white ; has largely disappeared from Eastern States; occasionally seen in winter.

\section{YELLOW-BELLIED WOODPECKER.}

Black, white, yellowish-Scarlet, black, yellowish.

81/2. Crown, crimson, black-bordered; throat, crimson; yellowish on back and abdomen; see 172.

\section{BAY-BREASTED WARBLER. \\ Olive, dark-streaked_Chestnut, whitish.}

$5 \% \frac{1}{2}$. Forehead and sides of head, black; crown, throat, upper breast, and sides, chestnut; wing-bars and tail-spots, white; abdomen, buff-white; $\&$ has duller chestnut markings.

Breeds on northern edge ; nest, rather large, of various materials, usually in hemlock, IO-20 ft. from ground ; eggs, middle of June, 4-6, bluish-green, marked; one of latest to arrive in spring, and rather rare.

\section{YELLOW LIST.}

Nos. 165-167: Showing Yellow, but no Black.

\section{YELLOW RED-POLL WARBLER: PALM WARBLER.} Olive, streaked_—Yellow, streaked.

5. Crown, chestuut; superciliary line, yellow; tail-feathers, white-spotted; below, yellow, faintly streaked with reddish-brown.

Exceptionally breeds on northern edge; occasionally winters in $\mathrm{S}$. N. J. ; nest, on ground ; first warbler (except " pine ") to arrive in spring; often found on ground; constantly firts tail. 


\section{ORANGE-CROWNED WARBLER.}

Olive-green_-Greenish-white, streaked.

$4 \frac{1}{2}-5$. Crown-spot, orange-brown; eye-ring and superciliary line, yellowish ; see $\mathbf{1 5 3}$.

\section{RUBY-CROWNED KINGLET.}

Greenish-olive_Y Yellowish-white.

$4-4 \frac{1}{2}$. See 1r\%. Sometimes quite yellowish below, and with or without ruby crown.

\section{BLACK AND YELLOW LIST.}

Nos. 168-175: Showing both Black and Yellow.

* Nos. 168-172: Throat and breast black (or ashy) and yellowe, or pure yellow.

\section{CONNECTICUT WARBLER.}

Olive-green_-Blackish-yellow.

$5 \frac{1}{2}$. Head, ashy; white eye-ring; below, except brownishash of throat and upper breast, yellow; difficult to distinguish from "mourning warbler," except by its white eyering.

Breeding-place not known; more abundant in fall than in spring.

\section{MOURNING WARBLER.}

Clear yellowish-olive-Black, yellow.

5-5 $\frac{1}{2}$. Head, ashy-gray; no white eye-ring; below, ex cept black throat and upper breast, bright yellow.

Breeds on northern edge, and in ints. of $\mathrm{Pa}$. ; nest, of leaves, grass, hair, on ground; prefers moist places; eggs, last of May, 4-6, white or creamy, variously marked ; called " mourning " from appearance of crape on throat where black is touched with gray. 


\section{CAPE MAY WARBLER.}

\section{Yellowish-olive-Yellow, black-streaked.}

5-51/2. Crown, blackish ; lore, black; side of head, yellow; ear-patch, reddish or orange-brown; back, yellowish-olive, dark-streaked; rump, rich yellow; large white patch on wings ; tail, white-spotted ; below, yellow ; throat, tinged with orange-brown; breast and sides, black-streaked; $q$, somewhat similar, but without so distinctive markings.

Breeds on northern edge; nest, near ground ; eggs, bluish-white, spotted with various shades; rare and beautiful.

\section{BLACK AND YELLOW WARBLER: MAGNOLIA WARBLER.}

Blackish-yellow_Y Yellow, black-streaked.

5. Above, very dark, except bright-yellow rump; forehead and broad band through eye, black ; crown, ash, bordered with white; prominent white patch on wing; tail, white-spotted; under tail-coverts, white; below, yellow; breast and sides, black-streaked.

Breeds on northern edge and occa. in mts. of $\mathrm{Pa}$. ; nest, in tree, near ground; eggs, early June, 4, dull white, finely dotted; showy.

\section{BLACK-CAPPED FLYCATCHING WARBLER: WIL- SON'S BLACK-CAP.}

Yellowish-olive_Bright yellow.

5. Forehead and sides of head, yellow ; crown, black; $q$ has obscure black crown, or none.

Breeds on northern edge; nest, said to be in bushes, with 4 eggs, white, dotted, but its nidification is rather uncertain. 
* * Nos. 173-175 : With throat scarlet or wutiti.

\section{YELLOW-BELLIED WOODPECKER.}

Black, white, yellowish__ Scarlet, black, yellowish.

$81 / 2$. Crown, crimson, bordered by black; 2 white stripes, separated by black, on side of face; back, black and yellowish; wings and tail, black and white; throat, scarlet; breast, black; abdomen, yellowish; $q$ has white on throat.

Breeds on northern edge; winters rarely in N. J.; nest, in hole; eggs, 4-6, pure white.

\section{WHITE-THROATED SPARROW: PEABODY BIRD.}

Reddish-brown, black-streaked-White, ashy.

7. White median line on crown, bounded by black band; white superciliary line; black eye-stripe; from bill to eye, bright yellow; 2 white wing-bars, not prominent; throat, white, bordered by black line; breast and sides, ashygray.

Breeds on northern edge; winters locally from Mass. southward; nest, on ground or in bush; eggs, June Ist, 4-5, very variable in color ; a handsome sparrow and a fair singer.

\section{1\%5. YELLOW-RUMPED WARBLER: MYRTLE WARBLER.}

Slaty, black-streaked, yellow-White, black, yellow.

$5 \mathrm{r} / 2$. Crown, rump, and spot each side of breast, yellow; 2 white wing-bars; tail, white-spotted; throat and abdomen, pure white; breast and sides, black and white; rump, always yellow; other yellow spots variable or absent in winter; $q$ and $s$, in winter, brownish, obscurely streaked.

Breeds on northern edge and rarely in mts. of $\mathrm{Pa}$. ; commonest warbler in spring; the only warbler remaining regularly in winter from Mass. southward, and locally abundant in S. E. N. Y. and N. J. ; nest, in low tree or bush; eggs, early June, $4-5$, white, marked. 


\section{BLUE OR RED LIST.}

Nos. 176, 177: Showing neither Black nor Yellow.

\section{1\%6. FOX SPARROW.}

Reddish-tawny-White, spotted.

7. See 152.

\section{6a. BAY-BREASTED WARBLER.}

Olive, streaked_Chestnut, whitish.

$5 \%$. See 164 .

\section{7\%. RUBY-CROWNED KINGLET.}

Greenish-olive_-Whitish.

4-4 $\frac{1}{2}$. Yellowish eye-ring; scarlet patch on crown in mature $\delta$, probably absent in $\$ ; 2$ whitish wing-bars; below, white, tinged with buff or yellow.

Possibly breeds on northern edge; nest, of feathers, hair, moss, etc. ; eggs, not described; remarkable singer for its size.

The following SUMMER BIRDS are only MIGRANT in PA. or N. J.; the bird's proper number precedes, its length follows, its name.

105. Henslow's Sparrow ; 5 ; in Pa., rare.

81. Savanna Sparrow; $5 \frac{1}{2}$; in $\mathrm{Pa}$.

139. Semipalmated Plover; 7 ; in Pa., rare.

143. Laughing Gull; $16-19$; in Pa., on Susquehanna River.

21. Olive-sided Flycatcher; $71 / 2$; in Pa. and N. J.

25. Traill's Flycatcher ; $5 \frac{1 / 2-6}{2}$; in Pa. and N. J.

29. Philadelphia Vireo; 5 ; in $\mathrm{Pa}$. and $\mathrm{N}$. J., rare.

8. LinCOLN'S SPARROW; $5 \frac{1}{2}$; in Pa. and N. J.

125. Yellow Rail; 6 ; in Pa. and N. J., rare. 
126. Florida Gallinule; $12-14$; in Pa. and N. J., rare.

5. Water Thrush; $5 \frac{1}{2}-6$; in N. J.

17. Short-billed Marsh Wren; $4 \frac{1}{2}$; in N.J.

27. SOlitary Vireo; $5 \frac{1}{2}$; in N. J.

55. Cerulean WARBLeR; $4 \frac{1}{2}$; in N. J., rare.

76. Nashville IVARbler; $4 \frac{1}{2}-5$; in N. J.

89. Canadian Flycatching Warbler; $5-5 \frac{1}{2} 2$; in N. J.

97. Blackburnian Warbler ; $4 \frac{1}{2}$; in N. J.

102. Black-throated Green Warbler; 5 ; in N. J.

\section{MIGRANT GROUP.}

WATER BIRDS.

Comprising those species whose migration is inland.

\section{AMERICAN SNIPE: WILSON'S SNIPE.}

Variegation of blackish, brown, and buff - White, brownstreaked.

ı. Bill, very long; tail, barred, very short; abdomen, white.

Breeds on northern edge and occa. in northeastern $\mathrm{Pa}$., chiefly in open, damp places; nest, on ground; eggs, 3-4, grayish-olive, strongly marked; game bird.

\section{SOLITARY SANDPIPER.}

Dark brown, white-speckled-White.

8-9. Tail, barred with black and white; sides of neck, brown-shaded and streaked; sides, black-barred; legs, dull green.

Breeds rarely on northern edge and locally in $\mathrm{Pa}$. ; nest, on ground; eggs, rare. 


\section{WINTER GROUP. \\ LAND BIRDS.}

Comprising those species that come down from the north in the fall, pass the winter within territory, and return north in spring.

\section{NEUTRAL LIST.}

Nos. 180-186: Showing neither Black, Yellow, Blue, nor Red.

180. BOHEMIAN WAXWING.

Orange-brown.

7-8. Crested; see 200, and compare with Cedar Waxwing, $\mathbf{2 5 5}$.

\section{SNOW BUNTING.}

Variegation of white and brown, with little black.

$61 / 2-7$. See 190.

\section{TITLARK : PIPIT : BROWN LARK: WAGTAIL.}

Dark brown_Light yellowish-brown, spotted.

$61 / 2$. Above, minutely streaked; superciliary line, buff; wings and tail, darker; outer tail-feathers, partly white; breast and sides, dark-spotted.

In summer, entirely beyond northern edge ; in winter, as far north as Mass., near coast, and occa. in S. Pa ; nest, crude, on ground; eggs, 4-5, dark chocolate ; feeble note, tremulous flight, and jerking tail.

\section{IPSWICH SPARROW.}

Grayish-brown-White, brown-streaked.

$61 / 4$. Median light crown-line; long whitish superciliary line ; 2 indistinct whitish wing-bars; a general rufous ap- 
pearance above ; throat and abdomen, pure white; otherwise, below, white, brown-streaked.

On coast of N. E., especially on sand-hills of Mass. and on those of N. J. ; some doubt as to its being a distinct species.

\section{BROWN CREEPER.}

\section{Variegation of browns - Whitish.}

$5 \%$. Bill, slender and decurved; faint whitish superciliary line; above, curious mixture of browns and white; tailfeathers, stiff and acuminate.

Breeds chiefly on northern edge and in $\mathrm{mts}$. of $\mathrm{Pa}$.; nest, usually lodged in crevice between bark of tree and main wood; eggs, about June Ist, 4-8, dull white, brown-spotted; always climbing trees.

\section{PINE FINCH : PINE LINNET : SISKIN.}

Flaxen, dark-streaked_Lighter.

43/4. Wings and tail, darker; variably suffused throughout with yellow; tail, emarginate.

Breeds on northern edge, in mts. of Pa., and exceptionally in Mass.; in winter, throughout; nest, high in tree; eggs, April and May, 4-5. light green, spotted; roams in large flocks; undulating flight and querulous note of goldfinch, its ally.

\section{WINTER WREN.}

\section{Dark wren-brown - Light brown.}

4. Superciliary line, whitish ; finely "waved" throughout with darker brown; tail, short and erect.

Breeds on northern edge and in $\mathrm{mts}$. of $\mathrm{Pa}$.; winter, Conn. and southward; nest, of hemlock twigs, feathers, moss, in hole or crevice ; eggs, last of May, 5-6, pure white speckled with reddish-brown. 


\section{BLACK LIST.}

II Nos. 187-194: Showing black, but no yellow NOR RED.

\section{BUTCHER-BIRD : GREAT NORTHERN SHRIKE.}

Bluish-ash —Whitish.

9-10. White superciliary line; broad black eye-stripe; wings and tail, black, both with large white spots; below, whitish, finely "waved" with black.

Breeds on northern edge; in winter irregularly south as far as $\mathrm{N}$. C. ; nest, in low tree or bush, of coarse material, softly lined; eggs, $4-6$, variegated with many tints ; disposition of hawk; has barbarous scream.

\section{BOHEMIAN WAXWING.}

Orange-brown.

7-8. Black forehead, eye-stripe, and chin; see $\mathbf{2 0 0 .}$

\section{SHORE LARK: HORNED LARK.}

Pinkish-brown —White, black.

$7-7 \% 2$. For winter plumage, see $\mathbf{2 0 1}$.

\section{SNOW BUNTING: SNOW-FLAKE.}

White, brown, black.

$6 x / 2-7$. Winter plumage, white, with much brown in endless variegation; blackish crown, and some black on back; summer dress, pure white; middle of back, wings, and tail, mostly black.

Breeds far north; in winter irregularly in Northern States, occa. to $N$. C. ; nest, of grass and moss, on ground; eggs, $4-6$, variable in color; often appears with snow-storm; commonly in large flocks. 


\section{SNOW-BIRD. \\ Slaty-black_Black and white.}

6-6 12 . Almost pure black on head; outer tail-feathers, pure white; below, throat and upper breast, black, passing abruptly into white beneath ; o has black replaced by dark brown.

Breeds on northern edge and in higher mts. of $\mathrm{Pa}$. and reported on Mt. Wachusett, Mass. ; in winter, throughout, abundant ; nest, usually on ground; eggs, June Ist, 4-5, variously tinted and marked; sprightly tinkling notes in winter, and pleasing song in spring.

\section{LAPLAND LONGSPUR.}

Brownish-black, buff-streaked-Black, white.

$6-61 / 2$. Winter plumage, as given; light superciliary line ; whole head, throat, and breast, black, overcast with brownish; grayish-chestnut collar; tail, dark, white-spotted; below, except throat and breast, white, dark-streaked on sides.

Breeds far north ; winter, throughout, but rare; no record in N. J.; nest, on ground; eggs, 4-6, dark, thickly spotted.

\section{HUDSONIAN CHICKADEE.}

\section{Olive-brown-Whitish.}

5. Throat, blackish; sides and rear, light brown.

Breeds on northern edge; in winter in N. E., but rare; highest authority fails to describe nest and eggs.

\section{3a. RED-BREASTED NUTHATCH: CANADA NUT- HATCH.}

Leaden-blue-Reddish-brown.

$4^{1} / 2-5$. See 199 . 


\section{WINTER WREN.}

Dark wren-brown-Light brown.

\section{See 186.}

I ๆ Nos. 195-199: Showing black AND RED, but no yellow.

\section{PINE GROSBEAK.}

Carmine, blackish_Carmine, gray.

8-9. Back, dark-streaked; wings and tail, blackish; 2 white wing-bars; below, fading to whitish on abdomen ; 9 , above, ashy-gray; head and rump, brownish-yellow ; below, lighter gray.

Breeds on northern edge ; winter, throughout, irregularly ; nest, of twigs and rootlets, lined ; eggs, 4, greenish-blue, spotted; in flocks, chiefly in evergreens.

\section{COMMON CROSSBILL.}

Brick-red, blackish_-Brick-red, gray.

6. Mandibles, crossed; head and rump, brightest red; wings and tail, blackish; \&, greenish-olive, dark-streaked; head and rump, yellowish ; below, greenish-gray.

Breeds on northern edge and in mts. of $\mathrm{Pa}$., where large flocks are found in winter; permanent in Ad'r'ks; known to breed in Feb. with snow $4 \mathrm{ft}$. deep! nest, in tree; eggs, in March or April, 4, greenishwhite, prettily spotted ; in flocks, commonly in evergreens.

\section{WHITE-WINGED CROSSBILL.}

Brick-red, blackish—Brick-red, gray.

6. Same as common crossbill, but with 2 white wingbars.

Habitat and habits as in common crossbill ; permanent in Ad'r'ks : eggs, pale blue, larger, and thickly spotted ; rare species; irregular; not found in N. J. 


\section{ARCTIC CHIPPER: TREE SPARROW.}

Reddish-brown, black-streaked-Ashy.

6. Crown, chestnut; whitish superciliary line; 2 prominent white wing-bars; throat and breast, ashy; dark spot in centre of breast.

Breeds far north; winter, abundant throughout; nest, in bush or on ground; eggs, $4-7$, pale green, finely dotted with reddish-brown; runs rapidly on ground; has a musical chatter.

\section{8^. RED-POLL LINNET.}

Flaxen, streaked-Rosy-tinged, streaked.

$5 \%$. See 204 .

\section{CANADA NUTHATCH: RED-BREASTED NUT-} HATCH.

Leaden-blue-Reddish-brown.

$4 \mathrm{y} / 2-5$. Whole top of head, black, bordered by white superciliary line; broad black eye-stripe; tail, black, whitespotted; below, reddish-brown, of various shades.

Nore abundant in migration; breeds in higher mts. of $\mathrm{Pa}$. and in Ad'r'ks; nidification, as in white-breasted nuthatch.

\section{YELLOW LIST.}

Showing Yellow, but no Black.

None.

\section{BLACK AND YELLOW LIST.}

Nos. 200-202: Showing both Black and Yellow.

\section{BOHEMIAN WAXWING.}

Orange-brown.

7-8. Crested; forehead, broad eye-stripe, and chin, black; a little white on wings; red horny appendages, like bits of 
sealing-wax, often on wings, occa. on tail; tail, broadly yellow-tipped; under tail-coverts, chestnut-red.

Infrequent, and seldom farther south than Mass., yet rarely to $\mathrm{Pa}$.; roams in flocks; the more northern analogue of cedar-bird, $\mathbf{2 5 5}$.

\section{SHORE LARK: HORNED LARK.}

Pinkish-brown-Yellow, black, white.

7-7 1/2. Summer dress: sides of face and throat, sulphur. yellow; black line across forehead and bordering crown, extended into a small tuft or horn; small black crescent under eye; large black crescent on breast ; tail, dark ; outer feathers, partly white; in winter, coloration paler, but yellow throat often conspicuous.

Breeds entirely north of territory, except occa. in Ad'r'ks ; flocks southward in winter, along coast, and rather common in E. Pa. and N. J. ; nest, slight, on ground; eggs, in April, 4-5, grayish, thickly spotted; allied to European "skylark."

\section{GOLDEN-CROWNED KINGLET.}

\section{Greenish-olive_-Whitish.}

$4-4 \frac{1}{2}$. Yellow patch on crown (its centre scarlet), bordered in front and on both sides by black stripe; superciliary line, whitish; 2 whitish wing-bars.

Breeds on northern edge; nest, chiefly of moss and feathers, hanging from low bough; eggs, 6-10, white, entirely speckled; our smallest winter bird.

\section{BLUE OR RED LIST.}

Nos. 203-205: Showing neither Black nor Yellow.

\section{PINE GROSBEAK.}




\section{3a. COMMON CROSSBILL.}

Brick-red, dusky.

\section{See 196.}

\section{3b. WHITE-WINGED CROSSBILL.}

6. See $19 \%$.

Brick-red, dusky.

\section{3c. TREE SPARROW: ARCTIC CHIPPER.}

Reddish-brown, streaked-Ashy.

6. Crown, chestnut; see $\mathbf{1 9 8}$.

\section{RED-POLL LINNET.}

Flaxen, dark-streaked-Rosy, whitish, dark-streaked.

$5 \frac{1}{2}$. Bill, yellow in winter ; crown, carmine; rump, rosywhite, dark-streaked; wings and tail, dusky; 2 white wingbars; below, white, streaked, except on abdomen; in mature $\hat{s}$, breast rosy-tinged; in $q$, rosy tint of rump and breast absent, or nearly so ; breast, dingy-yellowish, darkstreaked.

Breeds far north; in winter, irregular, throughout; nest, near ground; eggs, 4-5, pale blue, finely spotted; in flocks.

\section{AMERICAN MEALY RED-POLL.}

Brownish, dark-streaked-White, rosy-tinted.

$5 \frac{\pi}{2}$. Crown, carmine; rump, pure white, rosy-tinged; wings and tail, dusky; 2 white wing-bars; below, white; breast, rosy-tinged; slightly streaked on sides.

An Arctic species; in winter, only in northern part of N. E. 
The Following Summer and Migrant Birds are OCCASIONALLY FOUND IN WINTER:

57. RoBIN ; 9-10 ; throughout, more abundant southward.

175. YELLOW-RUMPED WARBLER ; $5 \frac{1}{2}$; Mass, and southward, regularly.

115. Purple Finch; 6 ; Mass. and southward.

67. Chewink; $8-8 \frac{1}{2} ;$ Mass. and southward.

87. MEADOW LARK; IO $1 / 2$; Mass. and southward.

174. White-throated Sparrow; 7 ; Mass. and southward.

158. White-Crowned SPARRow; 7 ; Mass. and southward, rare.

151. Hermit Thrush; 7-7 $1 / 2$; Conn. and southward. 36. MOCKING-BIRD; 9-IO ; Conn. and southward, rare. 108. BLUEBIRD; 61/2-7; Conn. and southward.

165. Yellow RED-POLL WARBLeR; 5 ; possibly north to Conn.

157. Rusty Grackle; 9 ; Conn. and southward, rare.

58. Cardinal Grosbeak; $81 / 2$; S. E. N. Y. and Pa.

32. COW-BIRD; $7 \frac{1}{2}$; rare.

65. RED-WVINGED BLACKBIRD; 9 .

56. MOURNING Dove; I2.

162. WiLd Pigeon; 16.

120. WOODCOCK; 10.

135. Night Heron ; 24.

The following ONLY in $P a$. or $N . J$.

81. Savanna Sparrow ; $51 / 2 ; \mathrm{S}$. Pa. and S. N. J.

6. Vesper Sparrow ; 6 ; S. Pa. and N. J.

68. Sivamp Sparrow; $51 / 2-6 ;$ S. Pa. and N. J.

70. Field Sparrotw; $5 \frac{1}{2} ; \mathrm{Pa}$. and S. N. J.

152. Fox Sparrow; 7 ; S. Pa. and N. J.

31. Purple Grachle; I2-13; Chester Co., Pa., and S. N. J. 138. Pied-billed Grebe; $13 ; \mathrm{Pa}$. (frequent) and N. J. (rare).

141. Kildeer Plover; 9-IO; S. Pa. 
3. Wilson's THRUSH; 7-7 $12 \%$; S. Pa.

131. Great Blue Heron; 42-50; N. J.

172. YELLOW-BELLIED WOODPECKER; $81 / 2 ; \mathrm{N}$. J.

16. Long-BILled Marsh Wren; 5-51/2; S. N. J.

17. ShorT-Billed Marsh Wren; $4 \frac{1}{2} 2$; S. N. J.

\section{WINTER GROUP.}

\section{WATER BIRDS.}

t Comprising the commonest found both on coast and in the interior in winter.

\section{CANADA GOOSE: COMMON WILD GOOSE}

$$
\text { Black, grayish-brown - Whitish-gray. }
$$

36. Head and entire neck, black, except white "bandage " on throat, nearly meeting on hind-head; tail, black; rest of body, grayish-brown finely "waved" with white; rear, white.

A northern species, found inland and on coast ; in Pa. only a common migrant; nest, on ground, occa. in tree ; eggs, $5-6$, dull greenish.

\section{COMMON LOON: GREAT NORTHERN DIVER.}

\section{Black-White.}

3I-36. Head, neck all round, back and wings, black; back and wings with numerous white spots ; throat, whitestreaked; ring of white spots around neck; below, pure white; sides, black-streaked.

A northern species, breeding rarely in territory, though comparatively common in Ad'r'ks; most abundant in winter; nest, on ground, by water; eggs, 2, greenish, thickly spotted. 


\section{HERRING GULL.}

Pearly-blue-White.

22-27. Tips of wings, black.

Abundant along coast and largest rivers ; rarely in $\mathrm{Pa}$. ; in summer, locally at large inland waters, particularly in Ad'r'ks; nest, on ground, occa. in tree; eggs, 3, greenish-gray, spotted; commonest gull.

\section{BUFFLE-HEAD DUCK.}

Black, white_White.

I4-I6. Head, large and puffy, iridescent with purple and violet; large white patch on side of face; much white on wings; locally abundant.

It Comprising those found regularly and not uncommonly on the coast, and on larger waters of $P a$. and $N$. J. in winter ( $a b$ breviated description).

\section{COMMON GANNET.}

3I. Goosc-shaped; white, except black half of wings; seldom on Jersey coast; not in $P a$.

\section{GREAT BLACK-BACKED GULL.}

3I. Above, dark slate; below, white; rare in N.J.; not in $P a$.

\section{GLAUCOUS GULL.}

30. Above, pale pearly-blue; below, white; no black; not in $P$ a. nor $N$. J.

\section{RING-BILLED GULL.}

18-20. Black band around bill, near tip; like herringgull (208), but noticeably smaller. 


\section{RED-THROATED DIVER.}

29. Head and neck, bluish-gray; hind-neck, whitestreaked; elsewhere, above, black; below, EXCEPT CHESTNUT THROAT, white; rare and irregular in $P$. and N. $J$.

\section{MERGANSER: FISH DUCK.}

24. Head and neck, lustrous-green; back and wings, black and white; below, pinkish-red; in Ad'r'ks in summer.

\section{RED-BREASTED MERGANSER.}

24. Head and neck, dark lustrous-green; back and wings, black and white; throat and breast, deep reddishbrown; elsewhere, below, pinkish-white.

\section{HOODED MERGANSER.}

19. Prominent crest, head, neck all round, and upper parts, black; below, from neck, white; sides, finely darkstreaked; rare; in Ad'r'ks in summer.

\section{WHITE-WINGED SCOTER.}

24. Pure black, except large white wing-patch, and white spot under eye.

\section{BLACK SCOTER.}

23. Pure black; rare in $P a$.

\section{SURF DUCK.}

23. Black throughout, except white patch on forchead and one on hind-head.

\section{GREATER SCAUP DUCK.}

20. Above, black; white patch on wing; throat and uhber breast, black; rest, white. 


\section{LESSER SCAUP DUCK.}

16. Almost identical with the last, except in size.

\section{LONG-TAILED DUCK: OLD SQUAW.}

15-20. Head, neck, fore-back, shoulders, several outer tail-feathers, throat, and abdomen, white; elsewhere, above, and breast, blackish; LONG TAIL-FEATHERS.

\section{THICK-BILLED GUILLEMOT.}

16-I9. Above, and entire neck, dark brown; below, from throat, pure white; the great "egg bird" of $N$. Pacific coast, having commercial value; not in $P$ a.

\section{KITTIWAKE GULL.}

16-18. Like herring gull, but only $2 / 3$ as cong; rare in N. J., accidental in $\mathrm{Pa}$.

\section{SEA-DOVE : DOVEKIE.}

81/2. Above, black; throat and breast, black, passing abruptly into white beneath; straggler in $P a$. 


\section{PERMANENT GROUP. LAND BIRDS.}

Comprising those species which, while the individuals may to a greater or less extent fluctuate with the spring and fall migrations, remain permanently represented, though in varying numbers, throughout the year.

\section{NEUTRAL LIST.}

Nos. 227-230 : Showing no Black, Yellow, Blue, nor Red.

\section{CANADA JAY: WHISKEY JACK.}

\section{Leaden-Gray.}

10-I I. No crest; above, dark throughout, except gray face and collar, and whitish-tipped wings and tail-feathers.

Resident on northern edge; non-migratory, and only casually southward, though observed rarely throughout ; nest, usually in evergreens; eggs, 3-4, variable in ground-tints and spots.

\section{CEDAR-BIRD : WAXWING.}

Creamy-brown.

6-7. Crested; for black and yellow markings, see $\mathbf{2 5 5 .}$

\section{SONG SPARROW.}

Reddish-brown black-streaked-Whitish, streaked. $53 / 4-61 / 2$. Streaks and blotch sometimes appear only dark; see 239. 


\section{AMERICAN GOLDFINCH.}

(Winter) Flaxen-brown-Lighter.

$43 / 4$. See 256.

\section{BLACK LIST.}

If Nos. 231-242: Showing black, but no yellow NOR RED.

* Nos. 231-238: Black throughout, or with conspicuous black head-markings.

\section{AMERICAN RAVEN.}

Black.

24. Iridescent.

Extremely rare, along coast, throughout Ad'r'ks, and in $\mathrm{Pa}$. and N. J.; mostly confined to extreme north, and west of Mississippi ; nest, high in tree or on cliff; eggs, 4-8, greenish, variously tinted and speckled.

\section{CROW.}

Black.

20. Iridescent.

Nest, bulky, in tree ; eggs, April or early May, 4-6, variable in tint and marking.

233. BLACK-BACKED, THREE-TOED WOODPECKER. Black, white - White.

8-9. Yellow crown-spot may escape notice; see $\mathbf{2 5 3 .}$

234. WHITE-BACKED, THREE-TOED WOODPECKER. Black, white-White.

8-9. Yellow crown-spot may escape notice; see $\mathbf{2 5 4 .}$ 


\section{EUROPEAN STARLING.}

Iridescent greenish-black, rusty-speckled.

$81 / 2$. Bill, long and grecnish-white.

Introduced and local, rare; nest, in tree; eggs, 4-7, pale greenish.

\section{CEDAR-BIRD : WAXWING.}

Creamy-brown.

6-7. Crested ; forehead, eye-stripe, and chin, black; yellow tip of tail may escape notice ; see $\mathbf{2 5 5}$.

\section{3\%. WHITE-BREASTED NUTHATCH.}

Black, ashy-blue —White.

6. Entire top of head and neck, above, glossy black; rest, above, ashy-blue; side of face, white; tail, black, with white markings.

Nest, of grasses, feathers, etc., in hole; eggs, June Ist, white, thickly spotted; commonly found climbing tree-trunks, often head downward.

\section{CHICKADEE : BLACK-CAPPED TITMOUSE.}

Black, ashy-Black, whitish.

5-51/2. Entire top of head, nape, and throat, black; side of face, white; below, the white quite "rusty" in winter.

Nest, of moss, hair, wool, etc., in hole of tree, post, or fence ; eggs, latter part of May, 6-8, white, spotted; in N. J. only in winter.

* * Nos. 239-242: With no evident black on head.

\section{BLUE JAY.}

\section{Purplish-blue - Whitish.}

II-12. Crested; forehead, black; wings and tail, blue, but black-barred and white-tipped; below, bluish-white on 
throat, black collar entirely round neck, breast otherwise gray.

Rarer in winter; nest, in tree-commonly evergreen-or bush; eggs, last of May, 4-5, variously tinted and spotted; screams much like a hawk.

\section{ENGLISH SPARROW.}

Reddish-brown, black-streaked-Black, ashy.

6. Chestuut border to crown; see $\mathbf{2 5 0}$.

\section{SONG SPARROW.}

Reddish-brown, black-streaked-Whitish, streaked.

$5 \frac{3}{4}-6 \frac{1}{2}$. Median line on crown, and superciliary line, whitish ; breast and sides, dark-streaked, with conspicuous blackish blotch on middle of breast.

Breeds throughout, and winters as far north as Mass., casually farther; sings in winter in $\mathrm{Pa}$. ; nest, on ground or low in bush; eggs, May Ist, 4-5, vary greatly in color; earliest general songster in spring.

\section{AMERICAN GOLDFINCH.}

Winter plumage (Oct.-Apr.), Flaxen-brown-Lighter.

43/4. No black crown; wings and tail, blackish; whitish wing-bars; $\$$, all the year like winter $\hat{o}$, but more oliveyellow above, and dingy-yellow below; wings and tail, dark, whitish-marked; for details, see $\mathbf{2 5 6 .}$

I T Nos. 243-250: Showing black AND RED, but no yellow.

\section{PILEATED WOODPECKER.}

Black throughout, except white and scarlet markings.

15-19. Crested ; crest and cheek-spots, scarlet; throat, long stripe on side of head and neck, with large area on wings, white; of has crest only slightly scarlet, and no scarlet on cheek.

Throughout, but more northerly, and only in deep woods. 


\section{FLICKER.}

Olive-brown-Cinnamon, black, whitish, spotted.

I2 $1 / 2$. Above, black-barred; black crescent on breast; scarlet crescent on nape ; see $\mathbf{2 5 2 .}$

\section{RED-BELLIED WOODPECKER.}

Scarlet, black, white-Whitish, reddish.

91/2-ro. Red eye; sides of head, whitish; entire crown and nape, scarlet; otherwise, above, finely banded with black and white; below, whitish, reddening on abdomen; o has only nape scarlet.

Southerly; casually in Conn. and northward; rare winter bird in N. J.

\section{RED-HEADED WOODPECKER.}

Crimson, blue-black, white.

$9 \frac{1}{2}$. Whole head and neck, crimson; back (except white rump), wings (except large white area), and tail, rich black ; rest, above and below, with aforesaid wing-area, white.

Seldom north of Mass. ; not found in N. J. in winter ; nest, in treehole; eggs, 4-6, white.

\section{4\%. HAIRY WOODPECKER.}

Black, white-White.

9-9 $1 / 2$. Head, black, with white stripes; scarlet band on nape; back, wings, and tail, black and white; $q$, without scarlet band.

Breeds north of Mass.; more abundant in winter; "quite plentiful " in Pa., also found in N. J.; nest and eggs, as in other woodpeckers. 


\section{DOWNY WOODPECKER.}

Black, white White.

6-7. Identical with "hairy" (except slight difference in tail-markings), but smaller.

More southerly range than "hairy," and more abundant; in orchards as well as woods; nest, in hole of tree; eggs, latter part of May, 4-6, white; sharp, rich note.

\section{TUFTED TITMOUSE.}

Dark ashy_-Whitish, chestnut.

$6-61 / 2$. Crested; black spot on forehead; below, whitish ; sides, chestnut.

North. to S. E. N. Y. ; nest, in hole ; eggs, 6-8, white, spotted.

\section{ENGLISH SPARROW.}

Reddish-brown, black-streaked-Black, ashy.

6. Forehead, lores, and throat, black; crown and rump, ash, former bordered by chestnut; spot behind ear and part of neck, chestnut, bordered on neck with white; prominent wing-bars.

Nest, early and late, simple; eggs, 4-5; an imported European nuisance.

\section{YELLOW LIST.}

Showing Yellow, but no Black.

\section{AMERICAN GOLDFINCH.}

Winter plumage (0ct.-Apr.), Flaxen-brown-Lighter.

$43 / 4$. Fore-part, all round, often distinctly tinged with yellow ; see $\mathbf{2 5 6 .}$ 


\section{BLACK AND YELLOW LIST.}

Nos. 252-257: Showing both Black and Yellow.

\section{GOLDEN-WINGED WOODPECKER: FLICKER.}

Olive-brown-Cinnamon, black, whitish, spotted.

121/2. Above, umber-brown, black-barred; scarlet crescent on nape; rump, white; tail, blackish above; wings and tail, bright yellow bencath; below, black maxillary spots; throat and upper breast, cinnamon, with black crescent on latter; other under parts, white, tinged and spotted.

Less abundant in winter, particularly north; nest, in tree-hole; eggs, middle of May, 6-7, pure white.

\section{BLACK-BACKED, THREE-TOED WOODPECKER.}

Black, white_White.

8-9. Crown-spot, yellow; sides of head, black-and-whitestriped; back, black; wings and tail, black and white; below, white; sides, black-barred; $q$, without yellow on crown.

Breeds north of Mass., common in Ad'r'ks; in winter rarely to Conn., not in $\mathrm{Pa}$. or N. J.; nest, chiefly in evergreens; eggs, pure white.

\section{WHITE-BACKED, THREE-TOED WOODPECKER.}

8-9. Like preceding, but with white line down the back, interrupted with black.

Breeds on northern edge ; more northern than "black-backed," and rarer; nest and eggs, as in "black-backed."

\section{CEDAR-BIRD : WAXWING.}

Creamy-brown.

6-7. Crested; forehead, broad eye-stripe, and chin, black; red spots, as of sealing-wax, often seen on wings, 
and occa. on tail ; tail, yellow-tipped; abdomen, yellow or yellowish; under tail-coverts, white.

Breeds throughout, remains in winter as far north as Mass.; nest, of grass, bark, roots, etc., in tree or bush, near ground; eggs, late June or early July, $3-6$, pale blue, black-spotted; no song, only a "wheezy whistle."

\section{AMERICAN GOLDFINCH.}

Summer plumage (Apr-Oct.), Black, yellow-Yellow. Winter plumage (Oct.-Apr.), Flaxen-brown-Lighter.

$43 \%$. In summer, throughout, bright yellow; crown, wings, and tail, black; wing-bars and tail-spots, white. In winter, wings and tail, blackish; fore-part of body often with yellowish suffusion.

Common throughout, the year round; in winter, in large flocks; nest, artistic, deeply cupped, 6-30 ft. from ground; eggs, early June, 4-6, bluish-white, unmarked; wavy fight on wing, and querulous or sad note in the song.

\section{5\%. EUROPEAN GOLDFINCH.}

Black, brown, yellow Light brown.

43/4. Entire front face and chin, scarlct; crown, black; side of face, white, bordered behind by black stripe ; back, soft brown; wings, black, with large yellow area; tail, black, white-spotted; below, white, irregularly shaded with soft brown.

Introduced, local, rare.

\section{BLUE OR RED LIST.}

Showing neither Black nor Yellow.

\section{TUFTED TITMOUSE.}

Dark ashy - Whitish, chestnut.

6-61/2. Crested; chestnut sides; see $\mathbf{2 4 9}$. 
Nos. 259-263.

\section{GAME BIRDS.}

\section{RUFFED GROUSE: PARTRIDGE.}

Ređđish-brown, spotted-Tawny, brown-barred.

I8. Erectile crown-feathers, black-marked; prominent dark ruff-feathers on each side of neck; tail, large and rounded, gray, with broad black band near tip, and elsewhere finely vermiculated with black.

Throughout; nest, on ground in swampy woods ; eggs, late in May, 8-15, buff, plain or spotted ; remarkable for "drumming."

\section{PINNATED GROUSE: PRAIRIE HEN.}

Barred with black, white, and tawny.

I6-18. Crested; a tuft of long feathers on each side of neck, which can be spread into the form of a little wing, below which the bare skin is sometimes greatly inflated; tail, very short; legs, feathered.

Very rare in Eastern States, but said to be still found in Martha's Vineyard, Long Island, and locally in N. Y., N. J., and Pa. ; nest, on ground; eggs, pale greenish-gray, speckled or unmarked.

\section{CANADA GROUSE: SPRUCE PARTRIDGE.}

\section{Black, gray-waved —-Black, white-barred, and spotted.}

I6. Narrow stripe over eye, yellow or red; broad, rounded tail, black, with broad tip of orange-brown; legs, feathered to toes; $q$, with much variegation of white, brown, and tawny; tail, obscurely orange-tipped.

Only on northern edge; locally common in Ad'r'ks; nest, on ground, in damp places; eggs, late in May, I2 or more, variegated. 


\section{2. “BOB-WHITE:" VIRGINIA PARTRIDGE: QUAIL.}

Variegation of brown, tawny, gray, etc.-Brownish and tawny, black-waved.

9. Crown-feathers, somewhat erectile ; forehead, superciliary line, and throat, white, and all black-bordered; ? has tints duller, and throat buff.

Throughout northward to Mass. ; nest, on ground; eggs, late in May, quite numerous, white; identified by notes resembling "bobwhite." Found in open fields.

\section{BLACK DUCK: DUSKY DUCK. (WATER-FOWL).}

\section{Blackish, feathers eaged with rusty-brown.}

24. Bill, greenish-yellow; violet patch on wing, blackbordered; legs, red.

Breeds throughout, but rarely in $\mathrm{Pa}$., where it is chiefly migrant, and locally in N. J., where it is common in winter on coast and large rivers; frequents ponds; nest, on ground, occa. in tree-hole; eggs, May and June, 6-ro, creamy or pale buff; one of the largest fresh-water ducks, and fine eating.

The Following Summer and Migrant Birds are PERMANENT IN PA. OR N. J.

173. Yellow-Bellied Woodpecker; $81 / 2 ; \mathrm{Pa}$, rare.

15. Great Carolina Wren; $51 / 2-6 ; \mathrm{Pa}$. and N. J.

108. Bluebird ; 6r/2-7; Pa. and N. J.

56. Mourning Dove; I2; Pa. and N. J., locally.

58. Cardinal Grosbeak; $81 / 2$; S. Pa. and N. J.

87. MEADOW LARK; IO $1 / 2 ; \mathrm{Pa}$. and N. J.

67. Robin ; 9-IO; N. J. ; not uncommon in $\mathrm{Pa}$. 


\section{Birds Found Only in N. Y., Pa., or N. J.}

Nos. 264-274.

\section{WHITE-RUMPED SHRIKE.}

Leaden-gray-White.

$8 \frac{1}{2}$. Stripe across forehead, continuous with broad bar on side of face, black; shoulders and upper tail-coverts, whitish; wings and tail, black, white-marked; below, sides shaded with gray, but no vermicular marking.

Only in Ad'r'ks, where it is not uncommon; habits, same as of other shrikes ; permanent.

\section{WILLOW PTARMIGAN.}

(Summer) Chestnut, variegated.

(Winter) White, black - White.

I5. Summer, fore-parts, chestnut, barred above and on sides with blackish, tawny, and white; most of wings, and below (except breast and sides), white; legs, feathered to claws; in winter, white throughout; tail, black, whitetipped; middle pair of tail-feathers, white.

Only in Ad'r'ks, and rare; permanent.

\section{WESTERN SHORE LARK.}

7. Coloration much as in shore lark (201), but very pale; black markings restricted.

A western species, breeding locally in W. Pa., and, it is said, in N. Y.

\section{6\%. EVENING GROSBEAK.}

\section{Yellowish, black, white.}

$71 / 2-81 / 2$. Forehead, superciliary line, shoulders and rump, yellow; crown, tail, and upper tail-coverts, black; body, olivaceous - yellow, becoming bright yellow posteriorly; wings, black and white, their under-side black and yellow; \& , brownish-ash, paler below, irreg. mixed with yellow.

A western species, since I8go locally permanent in Pa., N. Y., and N. J. 


\section{WILD TURKEY.}

\section{Iridescent copper-bronze.}

36-48. Bare skin of head and neck, blue; excrescences, purplish-red; upper tail-coverts, chestnut; tail, brown, black-barred; long tuft of blackish bristles hanging from middle of breast; legs, red; general plumage, copperbronze, each feather black-tipped; \& smaller and duller.

Pef ... tricts " of Pa., possibly in N. Y. (?) ; extirpated in N. E. and N. J. ; nest, on ground; eggs, much like those of domestic turkey, but a little smaller.

\section{BEWICK'S WREN.}

\section{Dark rufous-brown-Ashy-white.}

5\%2. Rump, grayish; flanks, brown.

Only in $\mathrm{Pa}$. and very rarely in N. J.; a summer bird ; nest, in hole of tree, etc. ; eggs, 7-9, white, sparsely speckled ; fine singer.

\section{YELLOW-THROATED WARBLER.}

Ashy-gray-Yellow, white.

5. Whole top of head, and patches on side of head and neck, black; long superciliary line, from bill to eye, yellow, from eye to nape, white; throat, rich yellow, black-bordered; other under-parts, white; sides, strongly blackstreaked.

Only in Pa. and S. N. J.; a summer bird; rare; nesting, unknown.

\section{CAROLINA CHICKADEE.}

$4 \frac{1}{2}$. Coloring of common chickadee (288), but much smaller.

Only in S. Pa. (summer) and N. J. (permanent). 


\section{BROWN-HEADED NUTHATCH.}

\section{Ashy-blue —Whitish.}

4. Top of head, down to eyes, brown, dark-bordered; white spot on nape.

Rarely breeding only in S. N. J. and rare straggler to S. Pa. ; habits of other nuthatches.

\section{2\%3. NELSON'S SHARP-TAILED FINCH.}

Smaller than sharp-tailed finch $(\boldsymbol{\gamma})$, but with same coloring, except "colors are brighter, and markings more sharply defined."

A western species, but a rare migrant on $\mathrm{N}$. J. coast.

\section{ACADIAN SHARP-TAILED FINCH.}

Size and coloring of sharp-tailed finch (7), "but paler and less conspicuously streaked beneath with pale greenish-gray."

A new subspecies, ranging along the coast; within territory only on $\mathrm{N}$. J. coast, where it is a regular migrant.

\section{RED LIST OF LAND AND WATER BIRDS.}

Including every shade from dark chestnut to scarlet. The bird's proper number precedes, its length follows, its name.

* Red the prevailing tint, even when not throughout, or with wings and tail black.

301. SCREeCh OWL; 8-10; in the "red phase."

195. Pine Grosbeak; 8-9; carmine; wings and tail, blackish.

58. Cardinal GrosbeaK; $81 / 2$; cardinal-red.

61. Scarlet Tanager; $71 / 2$; scarlet, except jet-black wings and tail. 
114. Summer TANAger ; $71 / 2-8$; vermilion.

152. FOX SI'ARROw; 7 ; reddish-tawny, or "rusty;" breast, white, spotted.

115. PURPLE FINCH ; 6 ; crimson, more anteriorly.

196. Common CRossbill; 6; brick-red; wings and tail, blackish.

197. White-Winged CRossbill; 6 ; brick-red; wings and tail, blackish.

* Red only on crown.

47. KING-BIRD ; 8 ; flame-colored spot, obscure.

198. TREE SPARROW; 6 ; bright chestnut.

250. ENGLish SPARROW ; 6 ; bright chestnut.

68. Sivamp Sparrow ; 51/2-6; bright chestnut.

69. Chipping SPARrow; $5 \mathrm{1} / 2$; bright chestnut.

41. OVEN-BIRD; 6 ; buff-orange stripe.

165. YeLLOW RED-POLL IVARBLER; 5 ; bright chestnut.

76. Nashville IVARBler; $4 \frac{1}{2}-5$; chestnut, obscure.

202. GOLDEN-CROWNed KINGLET; 4-4 $1 / 2$; scarlet centre of yellow spot.

177. RubY-CROTNED Kinglet ; $4-4 \frac{1}{2}$; entire spot scarlet.

* * Red only on nape.

252. FLICKER; I2 $1 / 2$; scarlet band.

247. HAIRY IVOODPECKER; 9-9 1/2; scarlet band.

243. DOWxy WOODPECKER; 6-7; scarlet band.

* * * Red only below, wholly or chiefly.

215. Merganser; 24 ; pinkish-red.

216. RED-BREASTEI) MERGANSER; 24 ; deep reddish-brown.

137. Summer DuCK; I9; chestnut.

121. KING RAIL; I7-I9; cinnamon-red. 
162. Wild Pigeon; 16 ; purplish-red.

146. RoseAte TERN; 12-16; rosy-tinted.

56. MOURNING DOVE; 12 ; purplish-red.

57. ROBIN ; 9-IO ; bright chestnut.

123. Virginia Rail; 8-IO; cinnamon-red.

108. BLUEBIRD; $61 / 2-7$; chestnut.

199. ReD-BREASted Nuthatch ; 4 $1 / 2-5$; reddish-brown.

**** Miscellaneous; arranged approximately according to order of descriptive details.

246. ReD-HEADED IVOODPECKER; $91 / 2$; head and neck, scarlet.

283. TURKEY BuZzARD; 24; red head.

144. ARCTIC TERN; I4-17; long bill, red.

145. CoMmon TERN; I3-I6; long bill and feet, red.

126. Florida Gallinule; i2-I4; bill and plate, red.

268. WiLd TURKEY, 36-48; excrescences, purplish-red.

257. European GoldFinch ; 43\% ; front face, red.

261. Canada Grouse; 16 ; superciliary line, red or yellow.

243. Pileated Woodpecker; I5-I9; crest and cheek, scarlet.

245. Red-Bellied WoodpeckeR; 91/2; crown and nape, scarlet.

173. Yellow-EELLIEd WOODPECKer ; $81 / 2$; crown and throat, scarlet.

170. CaPe MaY Warbler; 5-51/2; side of head, reddish or orange-brown.

204. ReD-POLL LiNnet; $51 / 2$; crown, carmine; rump and breast, rosy.

205. American Mealy Red-poll; 5 tra ; crown, carmine; breast, rosy.

109. Barn Swallow; 6-7; forehead and breast, chestnut.

112. Cliff Swallow ; $5-5 \frac{1}{2}$; side of head, rump, and throat, I chestnut.

164. BAY-BREASTED WARbler; $5 \frac{1}{2}$; crown, throat, and breast, chestnut. 
130. LEAST BITTERN; II-I4; hind-neck, chestnut.

136. GREEN HERON; I6-I 8 ; neck and below, dark reddish. 92. Prairie WARbler; $4 \frac{1}{2}$; middle of back, brick-red. 88. Baltimore ORIOLE; $7 \frac{1}{2}-8$; rump and breast, orange. 62. ORCHARD ORIOLE; 7 ; rump and lower breast, chestnut. 65. RED-IVINGED BLACKBIRD; 9 ; shoulder, scarlet. 285. RED-SHOULDERED HAWK ; 20 ; shoulder, reddish. 255. CEDAR-BIRD; 6-7; red spots on wings. 279. RED-TAILED BuZZARD; 22 ; tail, bright chestnut. 291. SPARROW HAIYK; IO-II ; tail, bright chestnut. 78. Great Crested Flycatcher; $81 / 2$; tail, chestnut.

63. REDSTART ; $5 \frac{1}{4}$; tail, wing-patch, and sides of breast, orange.

66. CAT-BIRD; 8 $1 / 2-9$; under tail-coverts, chestnut-red.

200. Bohemian Waxwing; 7-8; under tail-coverts, chestnutred.

118. Ruby-throated Humming-bird ; $3 \frac{1}{4}$; throat, ruby.

214. RED-THROATED DIVER ; 29 ; throat, chestnut.

59. Rose-Breasted Grosibak; $8-81 / 2$; upper breast, carmine.

97. BLAckBtrnian WARbleR; $4 \frac{1}{2}$; breast, orange.

101. Chestwut-sided Warbler; $51 / 2$; chestnut stripe on side of breast.

67. Chewink; $8-81 / 2$; sides, chestnut.

249. Tufted Titmouse; $6-61 / 2$; sides, chestnut.

263. BlaCK DuCK; 24; legs, red. 


\section{BIRDS OF PREY.}

These comprise cagles, hawks (and allies), and owls; the two former diurnal, the last nocturnal, in habits. Eagles and hawks are at once recognized by their great size, generally neutral coloring, frequent alternation of flapping and sailing in flight, and erect attitude in perching. They are generally silent, their occasional screams much resembling that of the blue jay. The peculiar physiognomy of owls instantly identifies the class. Bircls of prey are ranked as non-migratory, though in several species this is not strictly true, their movements northward and southward being probably induced by the varying conditions of foodsupply. As a rule they are not gregarious. It has recently been proved that this despised group of birds arc, almost without exception, far more beneficial than hurtful in nature's economy, their food being largely such animals as are noxious to the farmer.

\section{EAGLES.}

\section{BALD EAGLE.}

\section{Dark brown.}

36. Head, neck, and tail, white after 3 d year, until then uniformly colored; Ist year, very dark, somewhat whitespotted; 2d year, gray, and larger than ever after!

Throughout, permanent, on coast and along large inland waters; nest, on tree or crag; eggs, 2, whitish, unspotted; feeds chiefly on fish. 


\section{GOLDEN EAGLE.}

\section{Dark brown.}

36. Part of head, and neck, golden-brown; legs, feathered to toes; in young birds, tail white, with broad black tip.

Irregularly throughout, but nesting rather northerly, and in mountainous regions; occasionally, in winter only, in $\mathrm{Pa}$. and N. I. ; nest, huge, on crag, rarely in tree; eggs, $2-4$, white, spotted.

\section{HAWKS (and ALLIES).}

(Nos. 277-281 show conspicuous white.)

\section{7\%. OSPREY : FISH HAWK.}

Dark brown - White.

24. Head and neck, white, with broad black stripe from eye to neck; crown, black-streaked; below, white, slightly brown-tinged, and breast somewhat dark-spotted; tail, barred.

Breeds throughout; found on coast, and at large inland waters; nest, bulky, in tree, on rock or ground; eggs, May, 2-3, color variable; sometimes gregarious; fish diet.

\section{ROUGH-LEGGED HAWK: BLACK HAWK.}

Variegation of brown and white-White, brown-marked.

24. Tail, black-barred, but basal half pure white; below, white, variously dark-marked, often with wide brown band across abdomen; legs, feathered to toes.

Throughout in winter; frequents marshy places; nest, on tree or cliff; eggs, 3-4, varied coloring. 
BIRDS OF PREY-HAWKS (AND ALLIES) IO5

\section{HEN HAWK: RED-TAILED BUZZARD.}

Dark brown — Buffy-white, partly streaked.

22. Above, slightly marked with tawny and white; tail, above, bright chestunt, below, silvcry white, with white tip subtipped with black ; sides and abdomen, dark-streaked; plumage variable, but chestnut-red tail characteristic.

Permanent throughout; nest, bulky, high in tree; eggs, 3 , whitish. marked.

\section{MARSH HAWK.}

\section{Bluish-gray_-Whitish.}

16-18. Wings, blackish-tipped; upper tail-coverts, white; tail, brown-barred.

Breeds throughout; more or less permanent, especially in S. Pa.; nest, on ground; eggs, May, 4-5, with dull tints, obscurely marked; in marshy places; feeds on mice, toads, insects, etc.

\section{GYRFALCON.}

24. White, heavily marked with brown.

An Arctic species, occa. seen in N. E. in winter; nest, on cliff.

\section{GOSHAWK : PARTRIDGE HAWK.}

Slate_—White, dark-barred.

24. Blackish on head; white superciliary line; tail, with 4 wide dark bands.

Throughout, permanent, somewhat rare.

\section{TURKEY BUZZARD.}

\section{Blackish.}

24. Bill, white; head, red; skin of head with a few bristly feathers; wings, gray on under side; tail, rounded.

Permanent in S. N. J.; breeds in Pa., where it is permanent in some sections; roams northward rarely to $\mathrm{Me}$; nest, on grounrl; eggs, I-2, whitish, variously spotted; gregarious, sails an immense distance-one or two miles-without wing-beat. 


\section{CARRION CROW: BLACK VULTURE.}

Blackish.

24. Bill, yellowish; head, dark, with a few bristly feathers ; tail, square.

A southern species, regularly north only to N. C., but straggling even to Me. ; no records in N. J.; chiefly a coast-bird.

\section{HEN HAWK: RED-SHOULDERED BUZZARD.}

Reddish-brown — Lighter, dark-streaked and white-barred.

20. Shoulders, orange-brown; wings and tail, blackish, narrowly white-barred and white-tipped.

Permanent throughout; nest, high in tree; eggs, Apr., 2-4, color variable; quite abundant.

\section{COOPER'S HAWK: CHICKEN HAWK.}

Dark brown_-White, brownish-barred.

I8. Throat, almost pure white ; wings, dark-barred; tail, lighter, dark-barred and white-tipped.

Permanent throughout, but rarer in winter; nest, in high tree; eggs, Apr. or May, 3-5, white or tinted, obscurely marked.

\section{DUCK HAWK: PEREGRINE FALCON.}

Dark ash —Buff-white, spotted.

I8. Forchead, whitish; throat, pure white; tail, finely barred with dark and light; large black patch on cheek; breast spotted, sides barred, with black.

Breeds throughout; a mountainous species; winters irreg. in $\mathrm{Pa}$; ; rare ; nest, on tree or ground; eggs, 3-4. whitish, variously spotted; attacks liarge game, such as ducks, hares, etc. 


\section{BROAD-WINGED HAWK: BUZZARD.}

Dark brown - White, barred and streaked.

I8. Tail, barred, and tipped with white; dark patch on each side of throat.

Permanent throughout, but rarer northerly in winter; nest, in tree; eggs, 3-5, yellowish-white, dark-spotted.

\section{PIGEON HAWK.}

Dark ashy-blue_Fulvous, dark-spotted.

I3. Wings, white-spotted; tail, banded with black and whitish, and white-tipped ; throat, whitish ; breast, buffy, and brown-spotted; $\&$, above, ashy-brown; tail, banded obscurely with whitish.

Breeds from northern edge down to Mass., and in winter throughout; nest, in tree-hole or on branch; eggs, 4-5, variously colored.

\section{SHARP-SHINNED HAWK.}

\section{Dark brown - White, brownish-barred.}

I2. Throat, almost pure white ; wings, dark-barred; tail, lighter, dark-banded and white-tipped.

Permanent throughout, but rare in N. E. in winter, and in $\mathrm{Pa}$. in summer; nest, in tree or on rock; eggs, May or June, 4-5, variable in color; especially valiant and impetuous.

\section{SPARROW HAWK.}

\section{Cinnamon-brown-Buff, slightly spotted.}

IO-II. Crown, ashy-blue, with chestnut spot varying in size: tail, bright chestnut, black-barred and white-tipped; outer feathers, mostly white, and black-barred ; throat and rear, white ; breast, buffy, sparsely or not at all spotted ; $q$ has breast thickly dark-streaked.

Abundant throughout; nest, in tree-hole, etc. ; eggs, May, 5-7, much varied in color; the smallest hawk, and handsome. 


\section{OWLS.}

\section{GREAT GRAY OWL.}

Ashy-brown, "waved" and streaked.

24-30. Plumage, "waved" above, streaked below ; concentric light and dark rings on face.

An Arctic species, permanent, at least in Ad'r'ks, though rare, and, in winter, rarely southward to Pa. and N. J. ; nest, in tree ; eggs, 34, white.

\section{SNOWY OWL.}

White, somewhat dark-spotted.

24. Face, throat, and feet, whitest.

An Arctic species, but frequent throughout in winter; nest, usually on ground; eggs, 5-10, laid at irregular intervals, as in other owls, so that nest may contain fresh eggs and young birds.

\section{GREAT HORNED OWL.}

Finely mottled with several quiet colors.

24. Prominent dark ear-tufts; below, rather lighter; general plumage rather variable.

Throughout; no nest ; eggs, $3-6$, whitish, laid in tree-hole, etc., in Feb. or Mar. ; said to be laid sometimes in Jan. in Pa.

\section{BARRED OWL: HOOT OWL.}

Ashy-brown, barred with whitish.

I 8-20. Dark and light concentric rings around eye; below as above, but lighter.

Throughout; nest, coarse, in tree-hole; eggs, Apr., 3-4, white. 


\section{BARN OWL.}

Whitish-tawny, black-speckled.

16-17. Face, lighter (dark around eye), bordered with dark; wings and tail, brown-barred; below, lighter, sparsely dark-spotted.

Southerly ; north to Mass. ; nest, in barn, tower, tree, etc.; eggs, $3^{-6}$, yellowish-white ; in Pa. nest sometimes found latter part of Feb.

\section{HAWK OWL: DAY OWL.}

Dark brown, white-speckled-Brown and white, barred.

I6. Face, whitish, bordered with blackish; tail, narrowly whitish-barred; below (except throat, which is streaked), closely barred with brownish and white.

An Arctic species, possibly breeding in $\mathrm{Me}$; in winter, throughout N. E., very rare in $\mathrm{Pa}$. and $\mathrm{N}$. J.; nest, in tree; eggs, 4-6, whitish ; most diurnal of owls.

\section{LONG-EARED OWL.}

Variegation of fulvous and dark brown.

I4-I6. Prominent ear-tufts; face, tawny, dark-bordered.

Throughout, common, gregarious; nest, in tree-hole, on ground, or in deserted nest; eggs, middle of Apr., 3-6, white.

\section{SHORT-EARED OWL: MARSH OWL.}

Variegation of fulvous and dark brown.

I 4 1/2. Face, whitish; black around eye.

Throughout, often in marshes; nest, on ground; eggs, middle of Apr., 4-7, white ; occa. flying by day.

\section{RICHARDSON'S OWL.}

Chocolate-brown, white-spotted-White, dark-spotted.

10-12. Face, white, dark-bordered.

An Arctic species, rarely in N. E. in winter; nest, in tree; egฐ্ 2-6, white. 


\section{SCREECH OWL: MOTTLED OR RED OWL.}

\section{Brownish-gray, dappled with various tints.}

8-ro. Prominent ear-tufts, plumage variable; a smallsized "great horned;" another plumage has a very reddish cast.

Throughout, rather abundant; nest, coarse, in tree; eggs, Apr., $4-6$, white.

\section{SAW-WHET OWL: ACADIAN OWL.}

Chocolate-brown, white-spotted-White, dark-spotted.

7-8. Face, whitish, dark-bordered.

Throughout, quite rare in $\mathrm{Pa}$. and $\mathrm{N}$. J.; nest, in tree-hole; eggs, Apr., 4-6, white; the smallest of the owls; name, from its peculiar scream. 


\section{INDEX}

(Figures refer to the bird's proper number.)

\section{LAND BIRDS}

BEE-MARTIN, 47

Blackbird, Bronzed Crow, I56

Cow, 32

Crow, 3 I

Red-winged, 65

Bluebird, I08

Bob-White, 262

Bobolink, 49

Bunting, Black-throated, 99

Snow, I9o

Towhee, 67

Butcher-bird, I87

Buzzard, 288

Red-shouldered, 285

Red-tailed, 279

Turkey, 283

CARDINAL-BIRD, 58

Cat-bird, 66

Cedar-bird, 255

Chat, Yellow-breasted, 93

Chewink, 67

Chickadee, 238

Carolina, 27I

Hudsonian, I93

Chipper, Arctic, 198

Cow-bird, $3^{2}$
Creeper, Black-and-white, 43

Brown, 184

Crossbill, Common, I96

White-winged, I97

Crow, Carrion, 284

Common, 232

Fish, 30

Cuckoo, Black-billed, 45

Yellow-billed, 98

DOve, MOURNING, 56

EAGLE, BALD, 275

Golden, 276

FALCON, PEREGRINE, 287

Finch, Acadian Sharp-tailed, 274

Grass, 6

Nelson's Sharp-tailed, 273

Pine, 185

Purple, II5

Sea-side, 79

Flicker, 252

Flycatcher, Acadian, 24

Great Crested, 78

Least, 26 
Flycatcher, Olive-sided, 2I

Traill's, 25

Yellow-bellied, 8o

GNAT-CATCHER, BLUE-GRAY, 44 Goldfinch, American, 242, 256

European, 257

Goshawk, 282

Grackle, Bronzed, I56

Purple, 3 I

Rusty, I57

Grosbeak, Blue, $3^{8}$

Cardinal, $5^{8}$

Evening, 267

Pine, 195

Rose-breasted, 59

Grouse, Canada, 26I

Pinnated, 260

Ruffed, 259

Gyrfalcon, 28I

\section{HAIR-BIRD, 69}

Hawk, Broad-winged, 288

Chicken (Cooper's), 286

Duck, 287

Fish, 277

Hen, 279, 285

Marsh, 280

Partridge, 282

Pigeon, 289

Red-shouldered, 285

Red-tailed, 279

Rough-legged (Black), 278

Sharp-shinned, 290

Sparrow, 291

Hen, Prairie, 260

Humming bird, Ruby throated, II 8
| INDIGO-BIRD, 39

JAY, BLuE, 239

Canada, 227

KING-BIRD, 47

Kingfisher, Belted, I07

Kinglet, Golden-crowned, 202

Ruby-crowned, I77

LARK, BROWN, I82

Meadow, 87

Shore (Horned), 201

Western Shore, 266

Linnet, Pine, 185

Red-poll, 204

Longspur, Lapland, I92

Martin, Purple, 33

Maryland Yellow-throat, 96

Mocking-bird, 36

Night HAwK, I3

Nuthatch, Brown-headed, 272

Canada (Red breasted), I99

White-breasted, 237

ORIOLE, BALTiMORE, 88

Orchard, 62

Osprey, 277

Oven-bird, 4I

Owl, Barn, 296

Barred, 295

Great Gray, 292

Great Horned, 294

Hawk (Day), 297

Hoot, 295

Long-eared, 298

Marsh, 299

Richardson's, 300 
Owl, Saw-whet (Acadian), 302 Screech (Red), 30I

Short-eared, 299

Snowy, 293

PARTRIDGE, 259

Spruce, 26r

Virginia, 262

Peabody-bird, I74

Pewee, 5I

Phœbe, 22

Pigeon, Wild (Passenger), I62

Pipit, 182

Ptarmigan, Willow, 265

QUAIL, 262

RAVEN, AMERICAN, 23 I

Red-bird, Summer, II4

Red-poll, American Mealy, 205

Common, 204

Redstart, 63

Rice-bird, 49

Robin, 57

SHRIKE, LOGGERHEAD, 37

Great Northern, 187

White-rumped, 264

Snow-bird, I9I

Sparrow, Chipping, 69

English, 250

Field, 70

Fox, I52

Henslow's, I05

Ipswich, 183

Lincoln's, 8

Savanna, 8I

Sharp-tailed, 7

Song, 24I

Swamp, 68

Tree, 198
Sparrow, Vesper, 6

White-crowned, ${ }_{5} 8$

White-throated, I74

Yellow-winged, Io6

Starling, European, 235

Summer Yellow-bird, 75

Swallow, Bank, I9

Barn, Io9

Chimney, 34

Cliff (Eave), II2

Rough-winged, 20

White-breasted, 48

Swift, Chimney, 34

TANAGER, SCARLET, 6I

Summer, II4

Titlark (Wagtail), I 82

Titmouse, Black-capped, $23^{8}$

Tufted, 249

Thrasher, I

Thrush, Brown, I

Golden-crowned, 4I

Gray-cheeked (Arctic), I49

Hermit, I5I

Louisiana Water, 4

Olive-backed, I50

Song, 2

Water, 5

Wilson's, 3

Wood, 2

'Turkey, Wild, 268

VEERY, 3

Vireo, Philadelphia, 29

Red-eyed, 40

Solitary (Blue-headed), 27

Warbling, 28

White-eyed, 83

Yellow-throated, 72

Vulture, Black, 284 
WAGTAIL, I82

Warbler, Bay-breasted, I64

Black and Yellow, I7I

Black-capped Flycatching, I72

Black-poll, I6o

Black-throated Blue, I6I

Black-throated Green, IO2

Blackburnian, 97

Blue Golden-winged, IO4

Blue Yellow-backed, 77

Blue-winged Yellow, 95

Canadian Flycatching, 89

Cape May, I7o

Chestnut-sided, ror

Cœrulean, 55

Connecticut, I68

Hooded, 90

Kentucky, 94

Magnolia, I7 I

Maryland Yellow-throated, 96

Mourning, I69

Myrtle, 175

Nashville, 76

Orange-crowned, I53

Palm, I65

Parula, 77

Pine, 73

Prairie, 92
Warbler, Prothonotary, 74

Summer Yellow, 75

Tennessee, I54

White-throated, I03

Worm-eating, 42

Yellow Red-poll, 165

Yellow-rumped, I75

Yellow-throated, 270

Water Wagtail, 5

Waxwing, 255

Bohemian, 200

Whippoorwill, I2

Woodpecker, Black - backed,

Three-toed, 253

Downy, 248

Golden-winged, 252

Hairy, 247

Pileated, 243

Red-bellied, 245

Red-headed, 246

White-backed, Three-toed, 254

Yellow-bellied, I73

Wren, Bewick's, 269

Great Carolina, I5

House, I8

Long-billed Marsh, I6

Short-billed Marsh, I7

Winter, 186

\section{WATER BIRDS}

Bittern, AMERICAN, 129

Least, I30

COOT, AMERICAN, I27

DIVER, RED-THROATED, $2 \mathrm{I} 4$

Dovekie, 226
Duck, Black (Dusky), 263

Buffle-head, 209

Greater Scaup, 22I

Lesser Scaup, 222

Long-tailed, 223

Summer, I 37

Surf, 220 
EGRET, GreAt Whith, I32

Small White, I33

Gallinule, Florida, I26

Gannet, Common, 210

Goose, Canada, 206

Grebe, Pied-billed, I38

Guillemot, Thick-billed, 224

Gull, Glaucous, 2I2

Great Black-backed, 2II

Herring, 208

Kittiwake, 225

Laughing, I43

Ring-billed, 2 I $_{3}$

Heron, Great BLUE, I3I

Great White, I32

Green, 136

Little Blue, I34

Night, I35

Small White, I33

KITTIWAKE, 225

LoON, CoMmon, 207

MERGANSER, 2 I5

Hooded, 217

Red-breasted, 216
Petrel, Stormy, I 48

Plover, Kildeer, I4I

Piping, I40

Semipalmated, I39

Upland, II9

Rail, Carolina (Common), I24

Clapper, 122

King, I2I

Virginia, I23

Yellow, I25

SANDPIPER, SOLITARY, I79

Spotted, I42

Scoter, Black, 2 I9

White-winged, 218

Sea Dove, 226

Sea Swallow, I45

Snipe, American, 178

Tattler, Semipalmated, I2 8

Tern, Arctic, I44

Common, I45

Least, I47

Roseate, 146

WOODCOCK, I2O 
65353 

. 





SMITHSONIAN INSTITUTION LIBRARIES

||||||||||||||||||||||||||||||||||||||

39088000842641 